\title{
Effects of Partitioning Time and Temperature on the Microstructure and Mechanical Properties of a High Strength Microalloyed Steel
}

ali almasi

University of Tabriz

abbas kianvash ( $\square$ akianvash@tabrizu.ac.ir)

University of Tabriz

abolfazl tutunchi

University of Tabriz

\section{Research Article}

Keywords: Quenching and partitioning (Q-P), Retained austenite, Yield strength, Tensile strength, Hardness, Fracture elongation

Posted Date: May 13th, 2021

DOI: https://doi.org/10.21203/rs.3.rs-513087/v1

License: (c) (i) This work is licensed under a Creative Commons Attribution 4.0 International License. Read Full License 


\title{
Effects of Partitioning Time and Temperature on the Microstructure and Mechanical Properties of a High Strength Microalloyed Steel
}

\author{
Ali Almasi ${ }^{1}$, Abbas Kianvash ${ }^{2}$, Abolfazl Tutunchi ${ }^{3}$ \\ Department of Materials Engineering, Institute of Mechanical Engineering, University of Tabriz, Tabriz 51666-16471, Iran
}

\begin{abstract}
In the present study, in a quenching-partitioning (Q-P) process, the effects of partitioning time $(\mathrm{Pt})$ and partitioning temperature $(\mathrm{PT})$ on the mechanical and microstructural properties of a microalloyed Fe-0.21C-1.5Si-2.2Mn-0.054Al-0.08Ti steel were studied. The XRD and SEM results confirmed increases in retained austenite $\left(\gamma_{R}\right)$ volume fraction $\left(V_{\gamma_{R}}\right)$ and $\gamma_{R}$ carbon concentration by increasing Pt and PT. XRD patterns confirmed reduction in $V_{\gamma_{R}}$ by further increasing the Pt and PT over $500 \mathrm{sec}$ and $390{ }^{\circ} \mathrm{C}$, respectively, due to super-saturation of austenite $(\gamma)$ with carbon. PT of $390{ }^{\circ} \mathrm{C}$ and Pt of $500 \mathrm{sec}$ were recorded as the optimum values for PTs and Pts, which allowed the present steel to obtain higher formability and higher fracture strain characteristics, while retaining higher hardness and strength. The highest yield and tensile strength, hardness and fracture elongation were obtained for the sample partitioned at $390^{\circ} \mathrm{C}$ for about $500 \mathrm{sec}$, which were about 741MPa, $1366 \mathrm{MPa}, 424 \mathrm{HV}$ and $25.2 \%$, respectively.
\end{abstract}

Keyword: Quenching and partitioning (Q-P), Retained austenite, Yield strength, Tensile strength, Hardness, Fracture elongation.

\footnotetext{
1 almasi@tabrizu.ac.ir

2 akianvash@tabrizu.ac.ir (Corresponding author)

${ }^{3}$ ab.tutunchi51@tabrizu.ac.ir
} 


\section{Introduction}

Quenching and partitioning process (Q-P) has been developed over the last decade in order to improve the ductility of parts under the premise of ensuring the high strength [1]. Quenched and partitioned steel exhibits an excellent combinations of strength and ductility with a final microstructure containing ferrite, martensite $(\mathrm{M})$, and $\gamma_{R}$, which is suitable for body parts in a new generation of advanced automobiles [2]. In the Q-P process, austenitized steel is cooled down to a temperature named as quench temperature (QT), which is between M transformation starting (Ms) and finishing temperature $\left(\mathrm{M}_{\mathrm{f}}\right)$. After partitioning in a temperature range between $\mathrm{M}_{\mathrm{s}}-\mathrm{M}_{\mathrm{f}}$, the sample is cooled in water down to the room temperature [3].

The main aim of the Q-P process is to improve the steels ductility and strength simultaneously, which is performed by stabilization of the $\gamma_{R}$ below $\mathrm{M}_{\mathrm{f}}$. Suitable alloying elements such as, Ti, $\mathrm{Mo}, \mathrm{Nb}$... can suppress the sedimentation of carbides during partitioning and this will make it possible to enrich $\gamma$ by carbon which will result in the stabilization of austenite $[4,5]$. During service cycles, transformation of strain induced $\gamma_{R}$ to $\mathrm{M}$ can improve the sample's mechanical properties. Therefore, it is very important to control and optimize $V_{\gamma_{R}}$ in the steel during the partitioning process [6]. Austenite stability is affected by the partitioning temperature (PT), austenite grain size and carbon content in $\gamma_{R}$ [7-11]. It has been confirmed that an increase in the austenite carbon content results in an increase in the austenite stability against strain-induced transformation [12-14]. Furthermore, the presence of some elements such as $\mathrm{Ti}$, Mo and $\mathrm{Nb}$ in steel will cause simultaneous increase in strength and ductility $[15,16]$. Combination of these elements with some carbon lead to formation of carbides and thus improve the mechanical performance of steels $[17,18]$. Carbides can prevent the possible bainitic transformation, which will lead to subsequent increase in $V_{\gamma_{R}}[19]$. In the partitioning process, carbon atoms diffuse from $\mathrm{M}$ to $\gamma$ that lead to an increase in the austenite carbon content and therefore increase the austenite stability [20-22]. There are three main methods for Q-P process (Fig. 1). In method 1 (Fig. 1-a), the PT is constant and equal to the quenching temperature (QT). Partitioning in this case, will continue until the partial martensitic transformation is completed. In method 2 (Fig. 1b), PT is constant and almost greater than the QT. Method 2 which is called a 'II step process can be designed below or above Ms. In method 3 (Fig. 1-c) partitioning and M transformation are performed simultaneously [23]. 


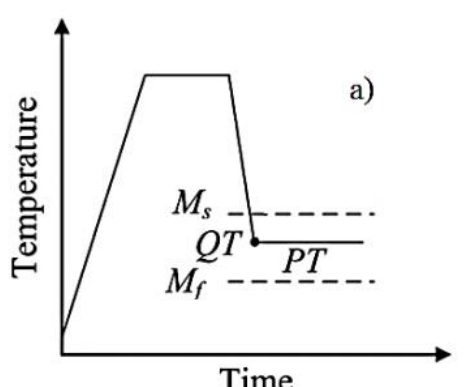

Time

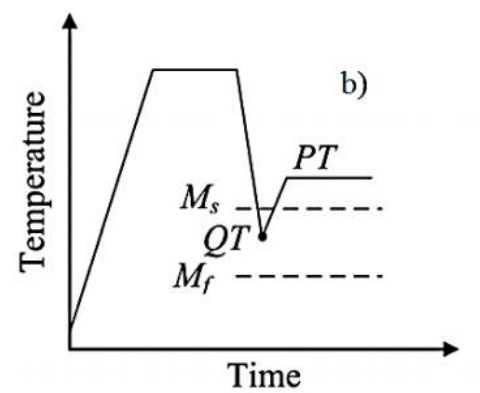

Time

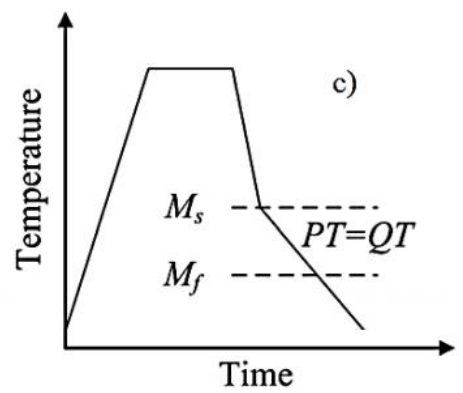

Time

Fig. 1. Three methods used in Q-P proccesses [23].

In all the three methods, carbon enriched $\gamma_{R}$ can again transform to $\mathrm{M}$ at low temperatures. Figure 2 shows the chemical free energy of $\gamma$ and $M$ versus temperature. At $\mathrm{T}_{0}$, the $\gamma$ free energy is equal to that of $\mathrm{M}$, which results in the coexistence of $\mathrm{M}$ and $\gamma$. Because of lower free energy, $\gamma$ is more stable above $\mathrm{T}_{0}$ and $\mathrm{M}$ is more stable below $\mathrm{T}_{0}$. At temperatures below $\mathrm{T}_{0}$, the transformation of $\mathrm{M}$ to $\gamma$, suppresses because of positive Gibbs free energy change $\left(\Delta \mathrm{G}^{\mathrm{o}}\right)$. At temperatures between $\mathrm{Ms}$ and $\mathrm{T}_{0}$ such as $\mathrm{T}_{1}$, undercooling is not enough to start the transformation but the transformation may start if sufficient mechanical driving force is introduced [24-26]. At temperatures above $\mathrm{T}_{0}$ such as $\mathrm{T}_{2}, \mathrm{M}$ to $\gamma$ transformation occurs spontaneously due to sufficient driving force. It is expected that an increase in the PT to $\mathrm{T}>\mathrm{T}_{0}$ leads to an increment in the $V_{\gamma_{R}}$ due to the more decreasing of $\Delta \mathrm{G}^{\mathrm{o}}$ and therefore increase in the transformation driving force. However, by further increase of PT, $\gamma$ could be supersaturated with carbon due to higher diffusion of carbon almost. This leads to reduction of carbon content in martensite and thus reduces the martensitic slabs strength [27-29]. Partitioning kinetics and therefore the sample microstructure and strength are strongly affected by Pt and PT. Therefore, the mechanical properties of the samples such as UTS and total elongation will be varied by Pt and PT. For most applications such as automobile bodies, the steel sheets must illustrate both higher UTS and higher fracture elongation [30]. Therefore, optimization of the partitioning parameters is very important in these types of steels, in order to attain higher UTS and ductility, simultaneously. The aim of the present research is to study the effects of Pt and PT on the microstructure, and mechanical properties of a high strength micro-alloyed Fe-0.21C-1.5Si2.2Mn-0.054Al-0.08Ti steel. 


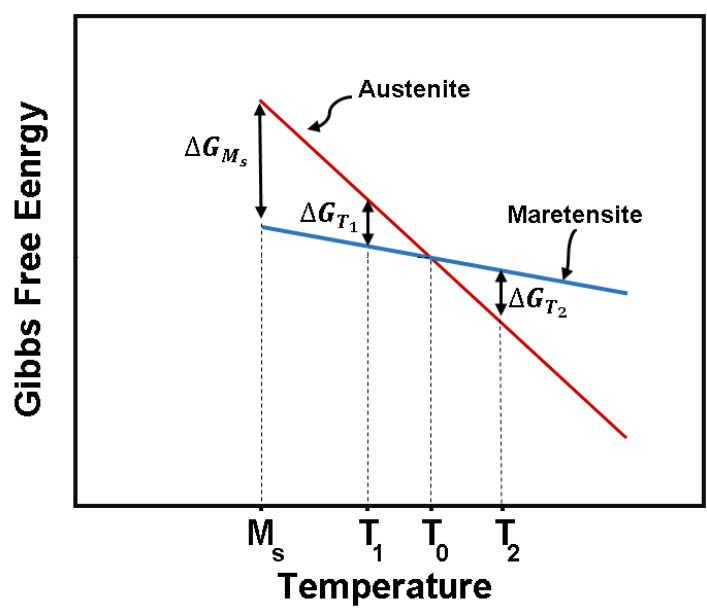

Fig. 2. $\gamma$ and M Gibbs free energy versus temperature.

\section{Experimental}

The chemical composition of the steel used in the present experiment is represented in Table 1 . The steel ingot was prepared by melting together the elemental components in a vacuum induction furnace. The cast ingot was then homogenized at $\sim 1200^{\circ} \mathrm{C}$ for about 180 min under an Ar atmosphere. If was then hot rolled at $\sim 1000^{\circ} \mathrm{C}$ in three passes to a thickness of around 1.5 $\mathrm{mm}$.

Table 1. Chemical composition of the steel used in the present experiment.

\begin{tabular}{cccccc}
\hline $\mathbf{F e}$ & $\mathbf{C}$ & $\mathbf{S i}$ & $\mathbf{M n}$ & $\mathbf{A l}$ & $\mathbf{T i}$ \\
\hline 95.5 & 0.21 & 1.5 & 2.2 & 0.054 & 0.08 \\
\hline
\end{tabular}

Time-temperature-transformation (TTT) diagram of the present steel was constructed using J.Mat.Pro software. The Ms of the steel determined by the J.Mat.Pro was compared with that of the one calculated by Rowland and Lyle equation [eq. 1] according to the steel chemical composition, in which $X_{\mathrm{i}}$ represents the elements concentrations in weight percentages [37].

$$
\mathrm{M}_{\mathrm{S}}\left({ }^{\circ} \mathrm{C}\right)=499-324 \mathrm{X}_{\mathrm{C}}-32.4 \mathrm{X}_{\mathrm{Mn}}-10.8 \mathrm{X}_{\mathrm{Si}}
$$

Ms determined by the software $\left(352^{\circ} \mathrm{C}\right)$ was quite comparable with that of the calculated one using Eq. $1\left(344{ }^{\circ} \mathrm{C}\right)$. The steel specimens in the form of tensile samples were first austenitized at $\sim 880^{\circ} \mathrm{C}$ for $5 \mathrm{~min}$ and were then quenched in molten bath at $\sim 300{ }^{\circ} \mathrm{C}$ and kept in it for $1 \mathrm{~min}$. To optimize the PT, six PTs of $290,310,330,370,390$ and $410{ }^{\circ} \mathrm{C}$ were examined according to Fig. 3a. After quenching, each sample was immediately transferred to a partitioning 
molten bath at one of the above temperatures and partitioned for $100 \mathrm{sec}$ and were then cooled to ambient temperature by water quenching. The effects of PT on the microstructure, YS, UTS, and fracture elongation of specimens were then studied in an attempt to optimize the PT. To optimize the Pt, 5 specimens were partitioned at the optimized PT for 10, 100, 300, 500 and $1000 \mathrm{sec}$ and then water quenched to ambient temperature (fig. 3b).
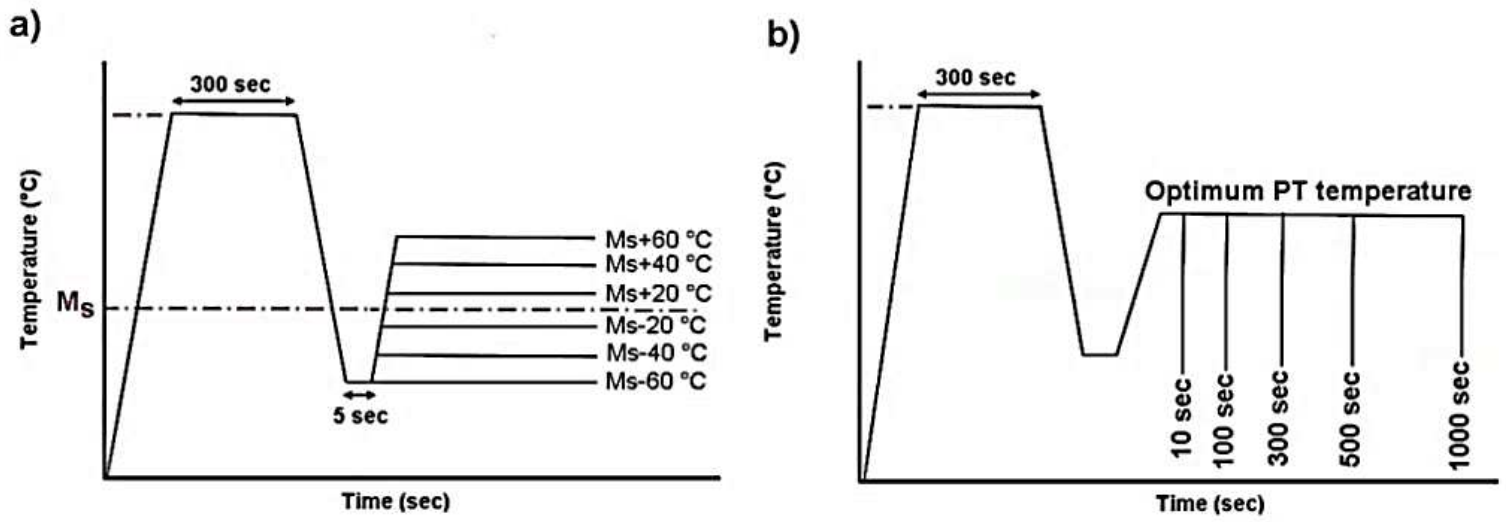

Fig. 3. Schematics of the Q-P process used in the present experiment partitioning at the various temperatures (a) and various times (b)

The phase analyses and microstructural studies of the samples were examined using X-ray diffraction (Siemens $\mathrm{D} 5000, \mathrm{Cu} \mathrm{K} \alpha$ radiation $(\lambda=1.54 \AA$ ) ) and scanning electron microscopy (SEM), respectively. The tensile properties and microhardness of the samples were measured using a universal stress-strain tester and a Vickers microhardness tester, respectively.

\section{Results and Discussion}

Thermo-Calc software was used to depict the steel's equilibrium phase diagram in order to define critical temperatures: $\mathrm{Ae}_{1}{ }^{\prime}, \mathrm{Ae}_{1}$ and $\mathrm{Ae}_{3} . \mathrm{Ae}_{1}$ ' represents cementite totally dissolving temperature (figure 4). $\mathrm{Ae}_{1}$ is the temperature at which austenite volume fraction is zero. At the temperatures below $\mathrm{Ae}_{1}$, microstructure of the steel involves ferrite and cementite. At the temperatures above $\mathrm{Ae}_{3}$, the sample will be completely austenitized. According to figure 4, the sample should be austenitized above $780{ }^{\circ} \mathrm{C}$. Furthermore, it is necessary to calculate $\mathrm{M}_{\mathrm{s}}$ in order to design the heat treating process. 


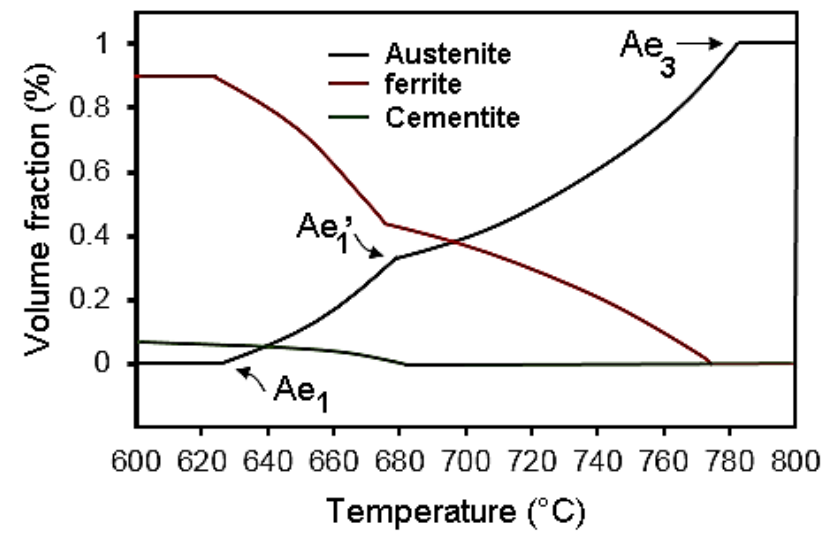

Fig. 4. Equilibrium $V_{\alpha}, V_{\gamma}$ and $V_{\mathrm{Fe}_{3} \mathrm{c}}$ vs temperature in the present steel determined using the Thema-Calc.

The T-T-T diagram of the present steel, which is constructed using the J.Mat.Pro package, is shown in Fig. 5. From this diagram, Ms was determined as $\sim 350{ }^{\circ} \mathrm{C}$ which is pretty close to one calculated using the Rowland and Lyle Eq. $\left(344{ }^{\circ} \mathrm{C}\right)$. A cooling rate of $\sim 126^{\circ} \mathrm{C} / \mathrm{sec}$ was recorded as the critical cooling rate. To suppress the formation of bainite, the austenitized samples at $880{ }^{\circ} \mathrm{C}$ must be cooled to QT by a cooling rate more than $126{ }^{\circ} \mathrm{C} / \mathrm{sec}$. In the present experiment, a cooling rate of $\sim 140{ }^{\circ} \mathrm{C} / \mathrm{sec}$ was selected as the first quenching step (cooling from austenitizing temperature to QT). The Partitioning temperatures (PTs) were selected as Ms \pm 60 ${ }^{\circ} \mathrm{C}$, thus they were chosen between $290-410{ }^{\circ} \mathrm{C}$, according to Fig. $3 \mathrm{a}$.

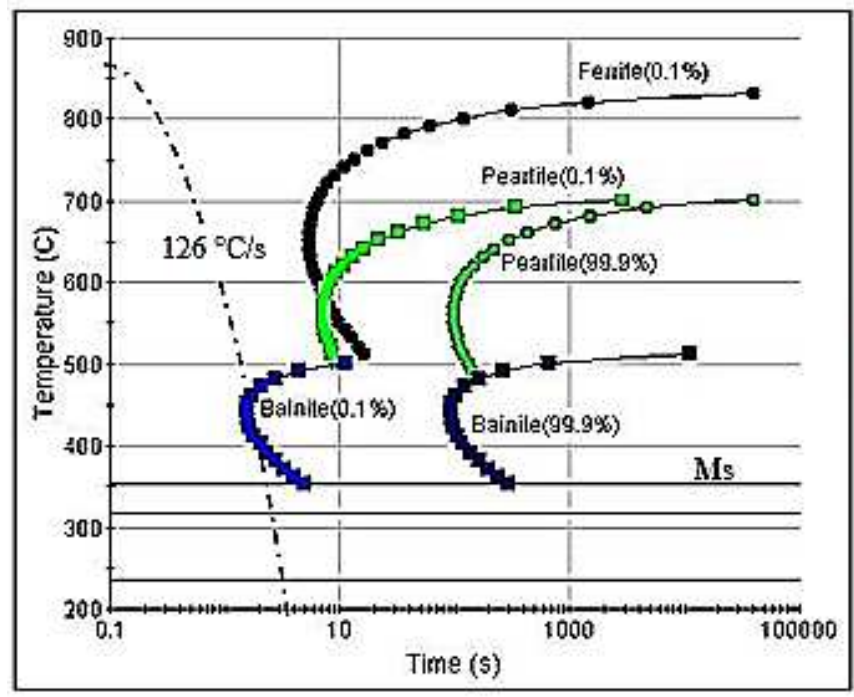

Fig. 5. TTT diagram of the present steel which is developed using the J.Mat.Pro package. 
SEM images of the samples quenched and partitioned in the temperature range of 290 $410{ }^{\circ} \mathrm{C}$ are shown in Fig. 6. The microstructure of all the samples were consisted of $\alpha$, M, and $\gamma_{R}$ phases, however, it seems that by increasing the PT, the $V_{\gamma_{R}}$ is increased.

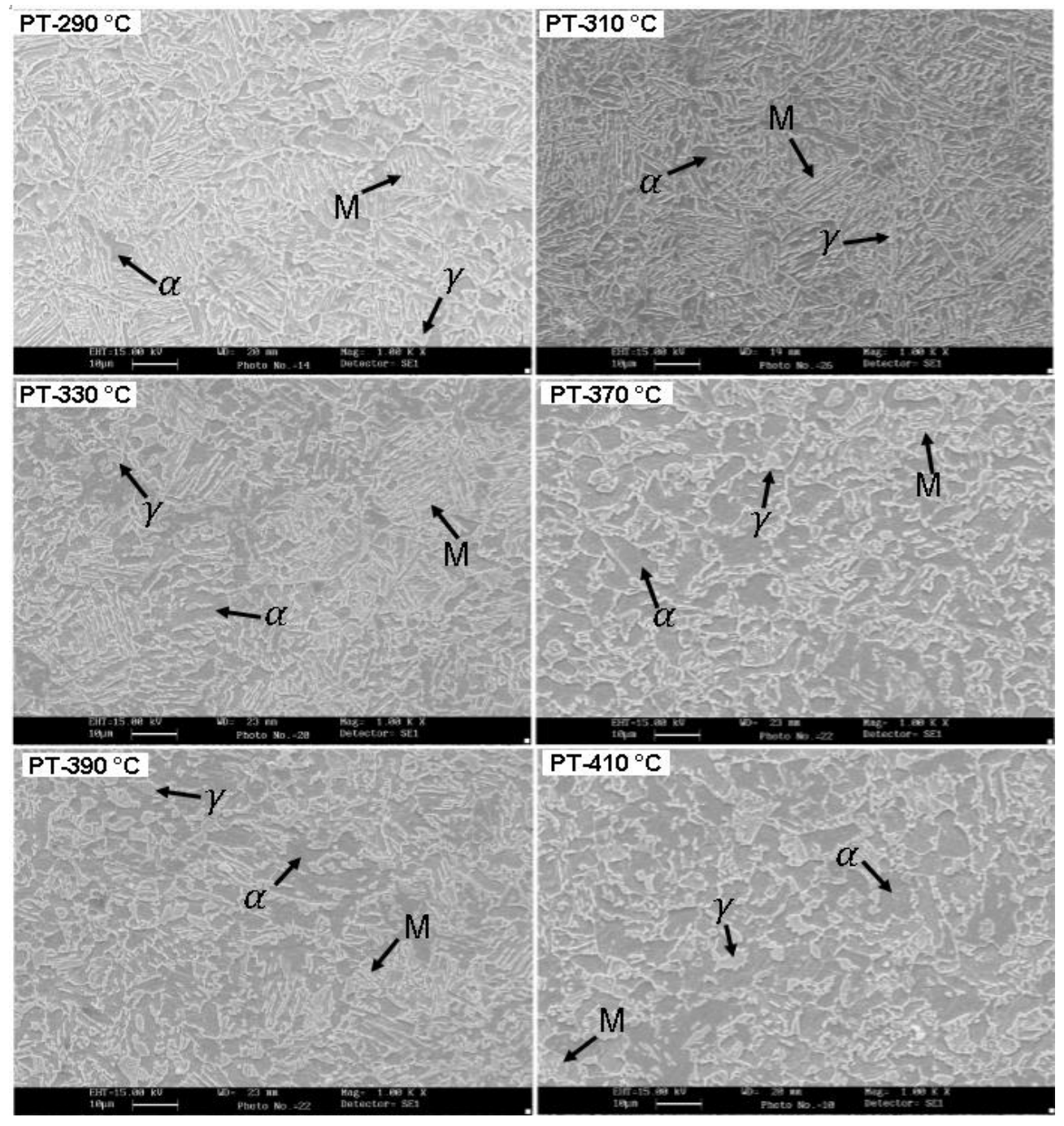

Fig. 6. SEM images of the samples partitioned at various temperatures

Figure 7 represents the XRD patterns for the samples partitioned at the temperatures of 290-410 ${ }^{\circ} \mathrm{C}$. The peaks assigned to $\gamma_{R}$ were found to be very weak in comparison to those of $\alpha$. $V_{\gamma_{R}}$ was calculated according to Eq. 2, in which $\mathrm{I}_{\gamma}$ is integrated (200) and (220) peaks intensity of austenite and $I_{\alpha}$ is integrated (200) peak intensity of martensite [16]. Carbon content in $\gamma_{R}$ was calculated in weight percentage using Eq. 3, in which $\mathrm{a}_{\gamma}$ is the lattice parameter of $\gamma_{R}$ calculated by Eq. 4, where $\lambda, \theta$, and h, k, 1 are the XRD laser source wavelength, diffraction angle and Miller indices of (200) plane, respectively [38-39]. 


$$
\begin{aligned}
& V_{\gamma}=1.4 I_{\gamma} /\left(I_{\alpha}+1.4 I_{\gamma}\right) \\
& C_{\gamma}=\left(a_{\gamma}-3.547\right) / 0.046 \\
& a_{(h k l)}=\frac{\lambda}{2 \cdot \sin \theta} \cdot\left(h^{2}+k^{2}+l^{2}\right)^{1 / 2}
\end{aligned}
$$

The structural characteristics of $\gamma_{R}$ in the samples partitioned at $290-410{ }^{\circ} \mathrm{C}$ are shown in Table 2. The variations in $V_{\gamma_{R}}$ and $\gamma_{R}$ carbon content $\left(C_{\gamma_{R}}\right)$ versus PT are shown in Fig. 8. There is an increasing tenderly in $V_{\gamma_{R}}$ and $C_{\gamma_{R}}$ by increasing the PT. The increase in $V_{\gamma_{R}}$ by increasing PT could be due to increase in $C_{\gamma_{R}}$ which the latter increases the $\gamma_{R}$ stability. By increasing PT to $410{ }^{\circ} \mathrm{C}, \gamma_{R}$ has been supersaturated by carbon, which has led to rejection of carbon from $\gamma_{R}$. This feature resulted in a decrement in $C_{\gamma_{R}}$ and $V_{\gamma_{R}}$, again.

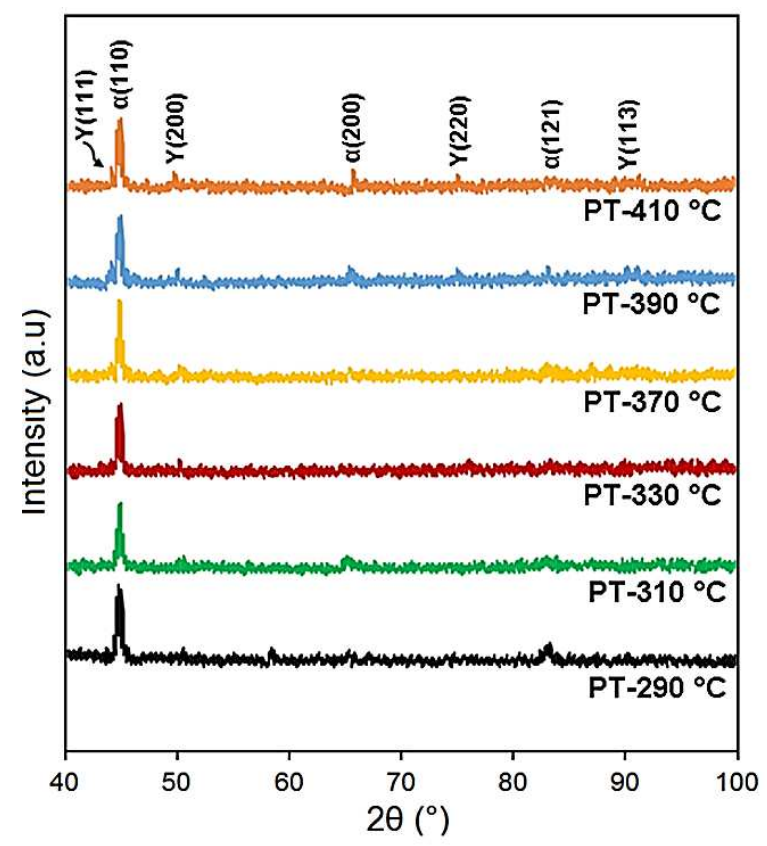

Fig. 7. XRD patterns of the samples partitioned at the temperature range of $290-410{ }^{\circ} \mathrm{C}$ 
Table 2. Structural characteristics obtained for the samples partitioned at the temperatures range of $290-410{ }^{\circ} \mathrm{C}$, using XRD patterns.

\begin{tabular}{|c|c|c|c|c|}
\hline Sample name & $\begin{array}{c}V_{\gamma} \\
(\%)\end{array}$ & $\begin{array}{c}\theta_{(200) \gamma} \\
\left(^{\circ}\right)\end{array}$ & $\begin{array}{c}\mathbf{a}_{\gamma} \\
\left({ }^{\circ} \mathbf{A}\right)\end{array}$ & $\begin{array}{c}\mathbf{C}_{\gamma} \\
(\mathrm{wt} . \%)\end{array}$ \\
\hline PT-290 ${ }^{\circ} \mathrm{C}$ & 7.68 & 25.11 & 3.63 & 1.88 \\
\hline PT- $310^{\circ} \mathrm{C}$ & 8.77 & 25.08 & 3.63 & 1.88 \\
\hline PT-330 ${ }^{\circ} \mathrm{C}$ & 9.84 & 25.03 & 3.64 & 2.07 \\
\hline $\mathrm{PT}-\mathbf{3 7 0}^{\circ} \mathrm{C}$ & 13.61 & 24.97 & 3.65 & 2.25 \\
\hline PT- $390^{\circ} \mathrm{C}$ & 28.1 & 24.58 & 3.70 & 3.40 \\
\hline PT $-410^{\circ} \mathrm{C}$ & 22.51 & 24.68 & 3.68 & 3.07 \\
\hline
\end{tabular}

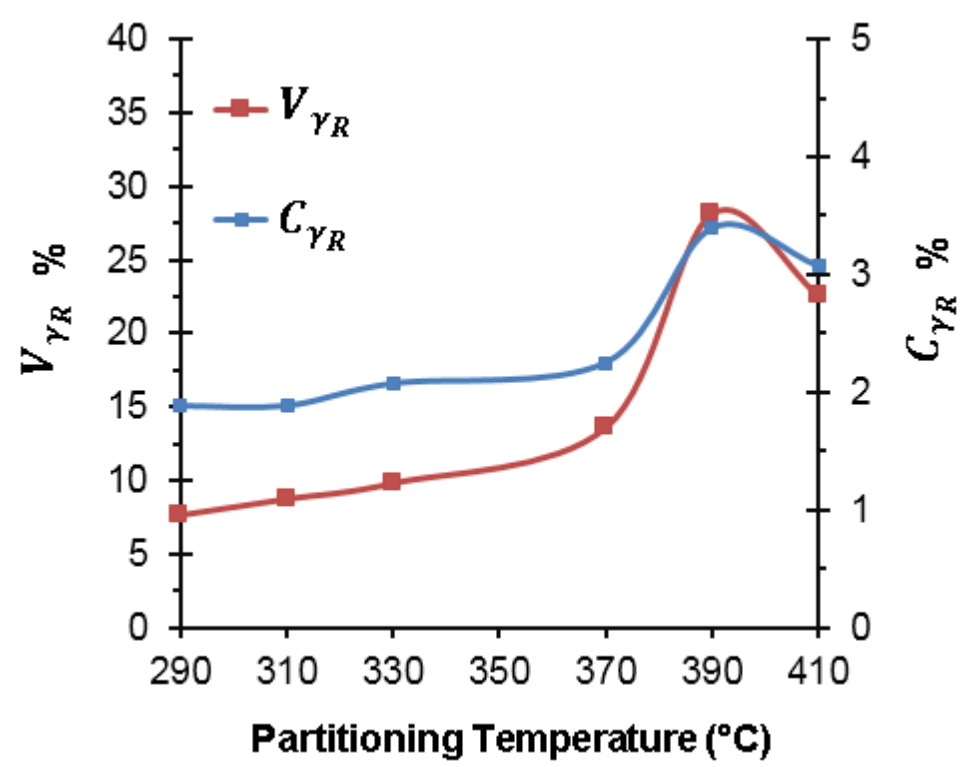

Fig. 8. $V_{\gamma_{R}}$ and $C_{\gamma_{R}}$ as a function of PT.

The study of steel behavior against sudden and rapid strain is also very important in the present experiment. The tensile stress-strain curves of the samples partitioned at the temperatures of $290-410{ }^{\circ} \mathrm{C}$ are shown in Fig. 9. The UTS, YS, and fracture strength of these samples are given in Table3. By increasing the PT from 290 to $390^{\circ} \mathrm{C}$, UTS of the samples increases from 786 to $1052 \mathrm{MPa}$. Further increasing the PT from 390 to $410^{\circ} \mathrm{C}$ resulted in a slight reduction in UTS value to $1035 \mathrm{MPa}$. This could be related to a reduction in $\gamma_{R}$ content in this sample in comparison to that of the sample partioned at $390{ }^{\circ} \mathrm{C}$. However YS increased by increasing the PT up to $410{ }^{\circ} \mathrm{C}$. The highest total elongation was obtained for the sample partioned at $370{ }^{\circ} \mathrm{C}$. 


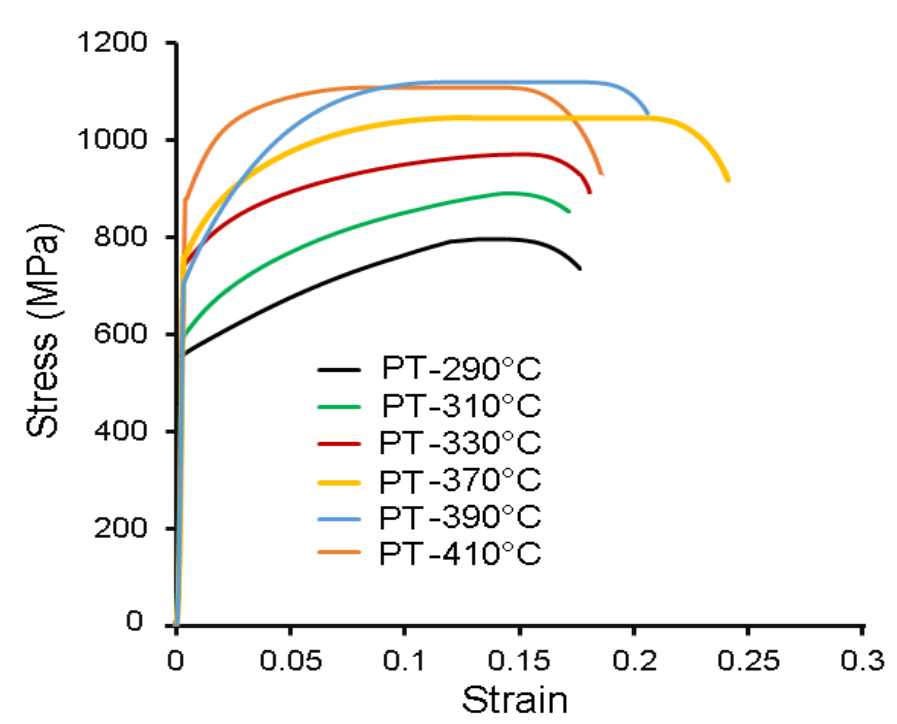

Fig. 9. The stress-strain curves for the samples partitioned at the temperature range of $290-410{ }^{\circ} \mathrm{C}$.

Table 3. UTS, YS and fracture strength of the samples partitioned at the temperature range of $290-410{ }^{\circ} \mathrm{C}$.

\begin{tabular}{cccc}
\hline $\begin{array}{c}\text { Sample } \\
\text { designation }\end{array}$ & $\begin{array}{c}\text { UTS } \\
(\mathbf{M P a})\end{array}$ & $\begin{array}{c}\text { Y.S } \\
(\mathbf{M P a})\end{array}$ & $\begin{array}{c}\text { Total Elongation } \\
(\boldsymbol{\%})\end{array}$ \\
\hline PT $-290^{\circ} \mathrm{C}$ & $786 \pm 7$ & $556 \pm 9$ & $17.59 \pm 0.7$ \\
\hline PT $-310^{\circ} \mathrm{C}$ & $895 \pm 7$ & $611 \pm 6$ & $17.52 \pm 0.4$ \\
\hline PT $-330^{\circ} \mathrm{C}$ & $953 \pm 5$ & $739 \pm 8$ & $18.16 \pm 0.9$ \\
\hline PT $-370^{\circ} \mathrm{C}$ & $1016 \pm 9$ & $767 \pm 9$ & $24.76 \pm 0.7$ \\
\hline PT $-390^{\circ} \mathrm{C}$ & $1052 \pm 8$ & $726 \pm 5$ & $18.25 \pm 0.6$ \\
\hline PT $-410^{\circ} \mathrm{C}$ & $1039 \pm 5$ & $865 \pm 7$ & $21.33 \pm 0.8$ \\
\hline
\end{tabular}

The variation in microhardness of the samples partitioned at $290-410{ }^{\circ} \mathrm{C}$ is shown in figure 10. The hardness of the samples increased from $338 \mathrm{HV}$ to $425 \mathrm{HV}$ by increasing the PT from $290{ }^{\circ} \mathrm{C}$ to $410{ }^{\circ} \mathrm{C}$. This could be attributed to increasing $C_{\gamma_{R}}$ by increasing the PT (Table 2).

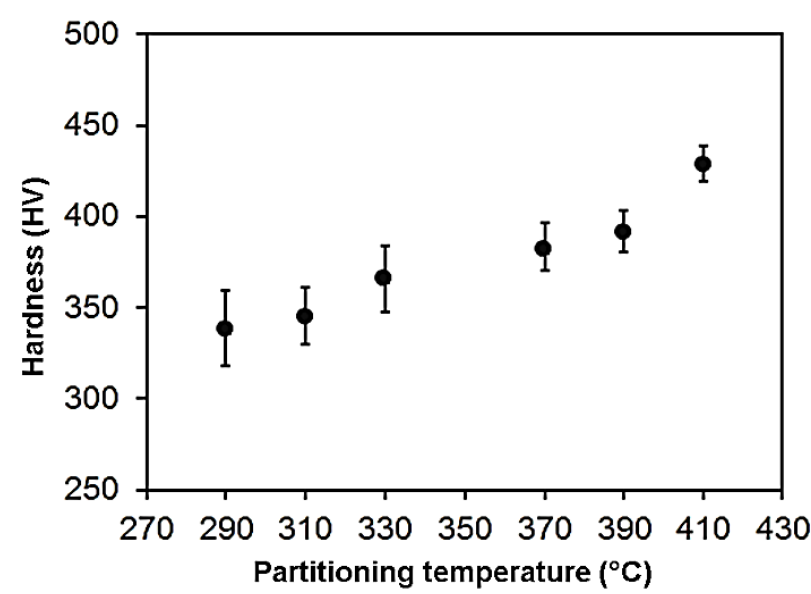

Fig. 10. Hardness of the samples partitioned at the temperature range of $290-410{ }^{\circ} \mathrm{C}$. 
According to the results obtained within the scope of the present study, the temperature interval of $370-410{ }^{\circ} \mathrm{C}$ was recognized as the suitable PT. Within this temperature interval, the PT of $390{ }^{\circ} \mathrm{C}$ was chosen as a typical suitable temperature to optimize the Pt. For this, Pts of 10, 100, 300, 500 and $1000 \mathrm{sec}$ at the PT of $390{ }^{\circ} \mathrm{C}$ were evaluated. SEM images of the samples partitioned at these Pts are shown in figure 11(a-e). $V_{\gamma_{R}}$ in the samples partitioned for 10 and $100 \mathrm{~s}$ was found to be relatively low. This could be related to insufficient time for carbon diffusion from $\mathrm{M}$ to $\gamma_{R}$. Thus, the dominant phase in the final microstructure of these samples was $\mathrm{M}$. $V_{\gamma_{R}}$ was continually increased by increasing Pt up to $500 \mathrm{sec}$ (figure 13). The XRD patterns for the samples partitioned at $390{ }^{\circ} \mathrm{C}$ for $10-1000 \mathrm{sec}$ are shown in figure 12 (a-e). The structural characteristics for these samples calculated from the XRD data, are summarized in Table 4. The highest $V_{\gamma_{R}} \%$ of $\sim 36.1 \%$ was obtained for the sample partitioned at $390{ }^{\circ} \mathrm{C}$ for $500 \mathrm{~s} . V_{\gamma} \%$ in the sample partitioned $390{ }^{\circ} \mathrm{C}$ for $1000 \mathrm{sec}$ was lower $\left(V_{\gamma}=34.7 \%\right)$ than that of the sample partitioned for $500 \sec \left(V_{\gamma}=36.1 \%\right)$. This could be due to relative supersaturation of $\gamma$ with $\mathrm{C}$ by extending the Pt to 1000 s.

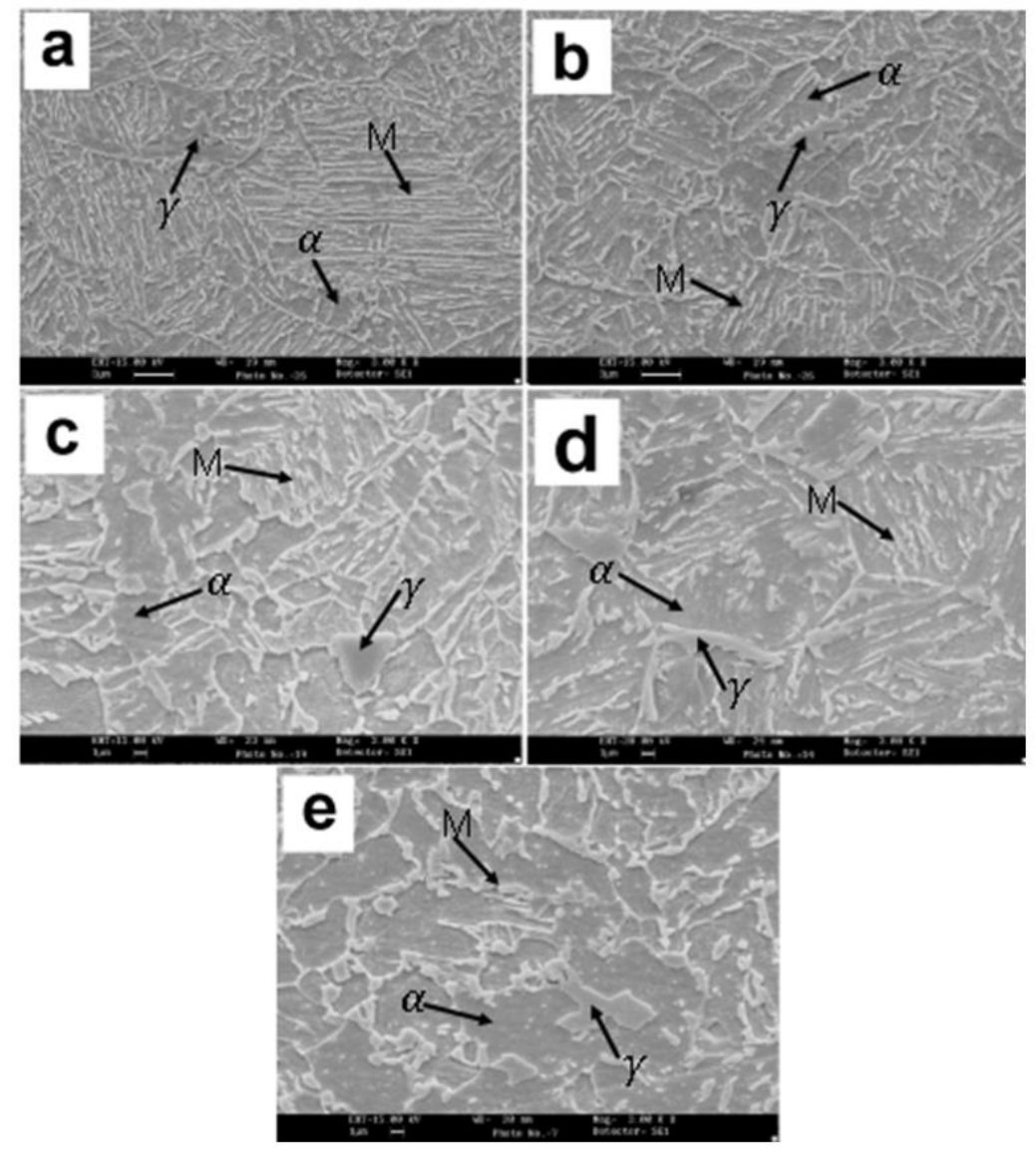


Fig. 11. SEM images of the samples partitioned at $390^{\circ} \mathrm{C}$ for $10-1000 \mathrm{sec}$.

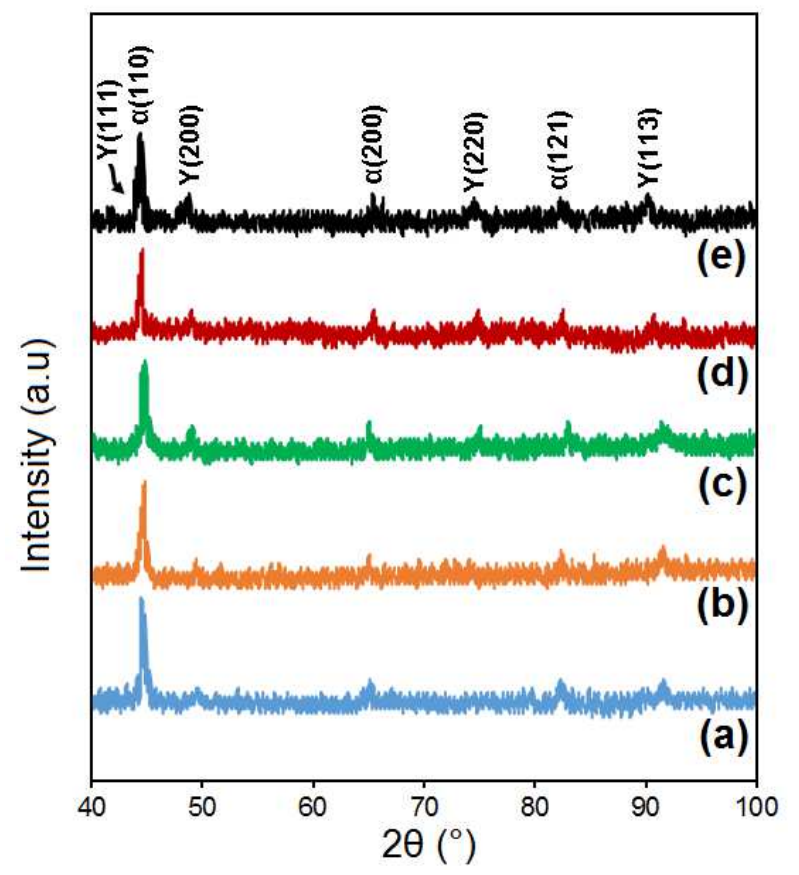

Fig. 12. XRD patterns of the samples partitioned at the temperature of $390^{\circ} \mathrm{C}$ for $10-1000 \mathrm{sec}$.

Table 4. Structural characteristics of the samples partitioned at $390^{\circ} \mathrm{C}$ for $10-1000 \mathrm{sec}$.

\begin{tabular}{ccccc}
\hline Sample name & $\boldsymbol{V}_{\boldsymbol{\gamma}_{R}}(\boldsymbol{\%})$ & $\boldsymbol{\theta}_{(\mathbf{2 0 0})_{\gamma}}\left({ }^{\circ}\right)$ & $\mathbf{a}_{\gamma}\left({ }^{\circ} \mathbf{A}\right)$ & $\boldsymbol{C}_{\gamma_{R}}(\mathbf{w t . \%})$ \\
\hline Pt-10 sec & 31.9 & 24.49 & 3.71 & 3.4 \\
Pt-100 sec & 32.6 & 24.45 & 3.72 & 3.59 \\
Pt-300 sec & 34.5 & 24.33 & 3.73 & 3.79 \\
Pt-500 sec & 36.1 & 24.29 & 3.76 & 4.38 \\
Pt-1000 sec & 34.7 & 24.31 & 3.74 & 4.19 \\
\hline
\end{tabular}




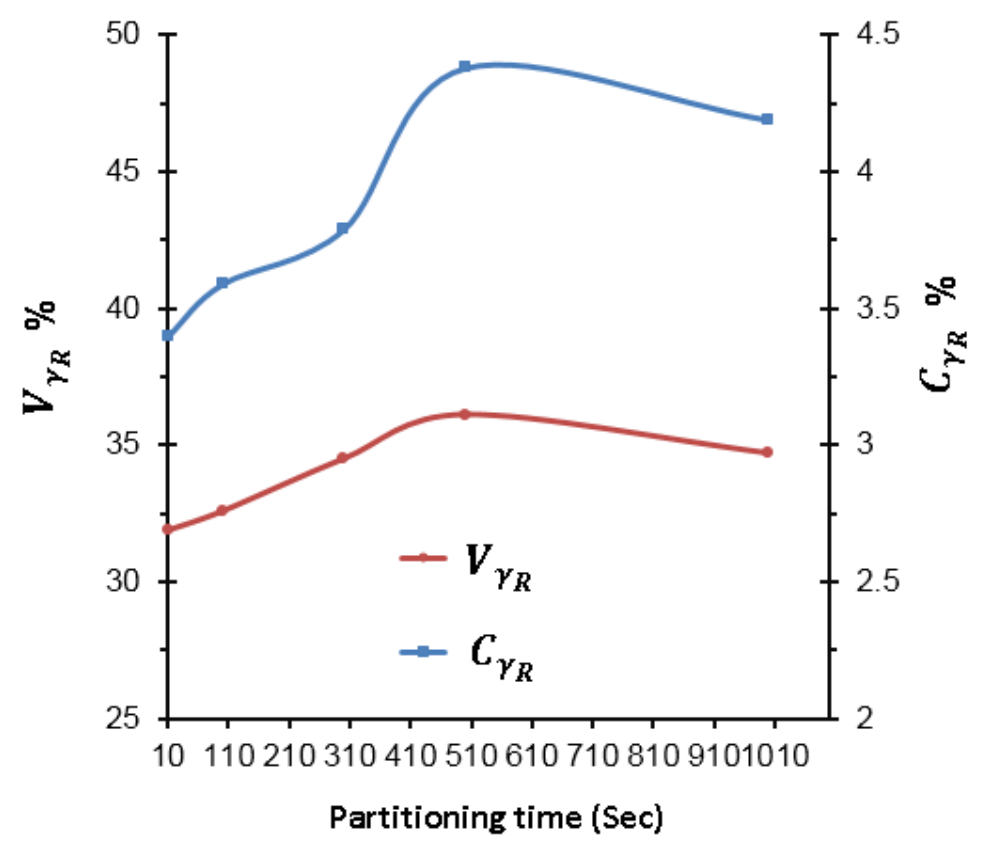

Fig. 13. $V_{\gamma_{R}}$ and $C_{\gamma_{R}}$ as a function of Pt.

The tensile stress-strain curves for the samples partitioned at $390^{\circ} \mathrm{C}$ for $10-1000 \mathrm{sec}$ are illustrated in figure 14. UTS, YS, and total elongation for these samples are given in Table 5. The YS of the samples was increased by increasing Pt up to $1000 \mathrm{sec}$, however, the UTS increased by increasing the Pt up to $500 \mathrm{sec}$ and then decreased by further increasing the Pt to $1000 \mathrm{sec}$ due to super-saturated of $V_{V_{R}}$ by carbon. The area under the stress-strain curves in the samples partitioned at $390^{\circ} \mathrm{C}$ for $300-500 \mathrm{sec}$ is larger than those of the other samples (figure 14). Thus, it could be concluded that the toughness (ductility) of the samples partitioned at $390^{\circ} \mathrm{C}$ in the time interval $300-500 \mathrm{sec}$ is higher than that of the others. The hardness of the samples partitioned at $390^{\circ} \mathrm{C}$ for $10-1000 \mathrm{~s}$ increased by increasing the Pt; i.e. from $296 \mathrm{HV}$ for $\mathrm{Pt}$ of $10 \mathrm{sec}$ to $441 \mathrm{HV}$ for the Pt of $1000 \mathrm{sec}$ (figure 15). Summarizing the results, it could be concluded that at $\mathrm{PT}$ of $\sim 390^{\circ} \mathrm{C}$, a $\mathrm{Pt}$ of $500 \mathrm{~s}$ is the best for Q-P process for the steel investigated in the present research. 


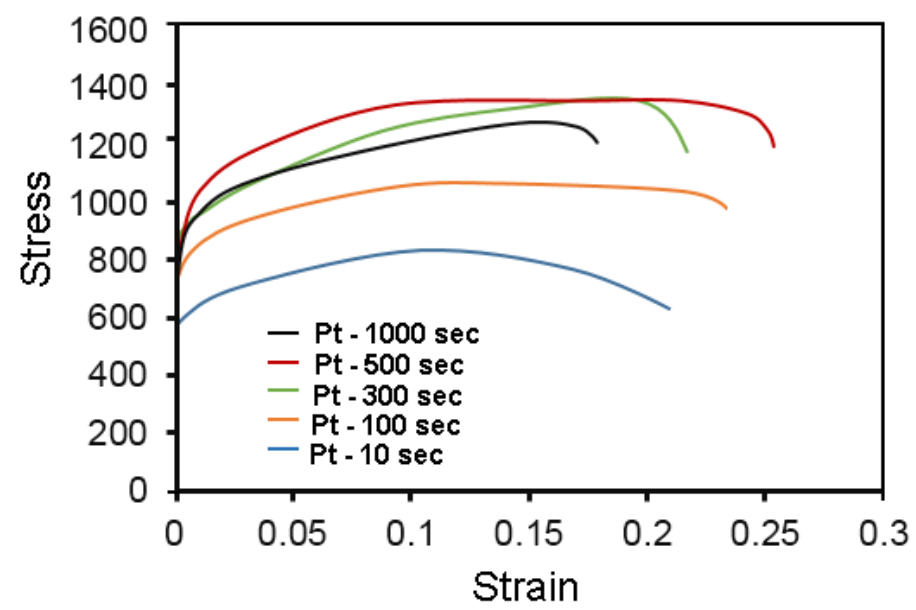

Fig. 14. Stress-strain curves for the samples partitioned at $390^{\circ} \mathrm{C}$ for $10-1000 \mathrm{sec}$.

Table 5. Mechanical properties of the samples partitioned at $390{ }^{\circ} \mathrm{C}$ for $10-1000 \mathrm{sec}$.

\begin{tabular}{cccc}
\hline $\begin{array}{c}\text { Sample } \\
\text { designation }\end{array}$ & UTS $(\mathrm{MPa})$ & Y.S $(\mathrm{MPa})$ & Total Elongation $(\%)$ \\
\hline Pt-10 sec & $846 \pm 4$ & $556 \pm 4$ & $21.32 \pm 0.5$ \\
\hline Pt-100 sec & $1075 \pm 9$ & $733 \pm 7$ & $23.82 \pm 0.9$ \\
\hline Pt-300 sec & $1353 \pm 5$ & $742 \pm 5$ & $21.96 \pm 0.4$ \\
\hline Pt-500 sec & $1366 \pm 3$ & $741 \pm 9$ & $25.18 \pm 0.6$ \\
\hline Pt-1000 sec & $1256 \pm 7$ & $761 \pm 3$ & $17.75 \pm 0.9$ \\
\hline
\end{tabular}

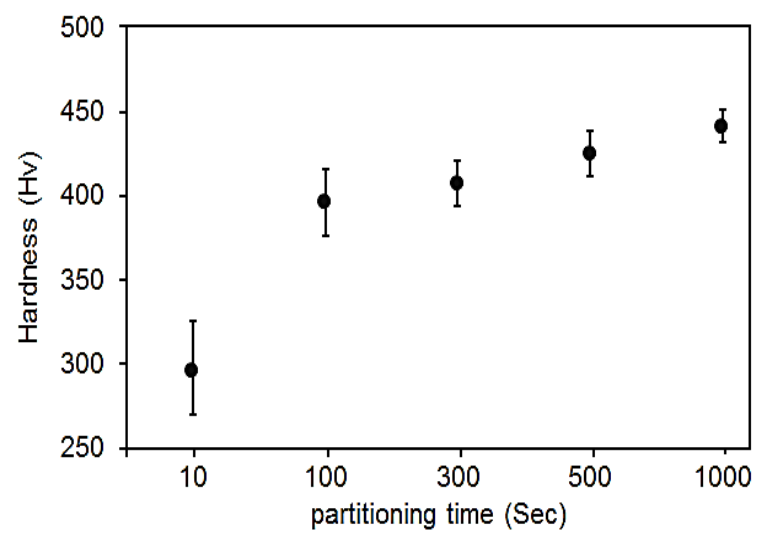

Fig. 15. Hardness of the samples partitioned at $390^{\circ} \mathrm{C}$ for $10-1000 \mathrm{sec}$.

\section{Conclusions}

The $V_{\gamma_{R}}$ in the Q-P process is effectively controlled by PT and Pt; i. e. by increasing the PT or Pt in their suitable range, $V_{\gamma_{R}}$ is increased. $V_{\gamma_{R}}$ in the partitioned samples was increased from 7.68 to $28.10 \%$ by increasing the PT from 290 to $390{ }^{\circ} \mathrm{C}$ and then decreased to $22.51 \%$ by further increasing the PT to $410{ }^{\circ} \mathrm{C}$. By increasing the PT from 290 to $390^{\circ} \mathrm{C}$, the UTS values increased from 786 to $1052 \mathrm{MPa}$. Further increasing the PT to $410^{\circ} \mathrm{C}$, resulted in some reduction in UTS value due to probable lower $V_{\gamma_{R}}$ compared to sample Partitioned at $390{ }^{\circ} \mathrm{C}$. The hardness 
of samples increased from 338 to $425 \mathrm{HV}$ by increasing the PT from 290 to $410{ }^{\circ} \mathrm{C}$; this could be attributed to increasing content of carbon in $\gamma_{R}$. Increasing Pt from $10 \mathrm{sec}$ to $500 \mathrm{sec}$ at PT of $390{ }^{\circ} \mathrm{C}$ resulted in an increase in $V_{\gamma_{R}}$ from 31.9 to $36.1 \%$. The $V_{\gamma_{R}}$ in the sample partitioned at $390{ }^{\circ} \mathrm{C}$ for $1000 \mathrm{sec}$ showed some reduction in comparison to that of the sample partitioned at that temperature for $\sim 500 \mathrm{sec}$; this could be related to supersaturation of $\gamma$ with carbon by increasing the Pt to $1000 \mathrm{sec}$. By increasing the Pt up to $1000 \mathrm{sec}$ at PT of $390{ }^{\circ} \mathrm{C}$, a significant increase in the carbon content of $\gamma_{R}$ can occur. However, the UTS and total elongation of these samples increased up to the Pt of $500 \mathrm{sec}$ and then decreased in the sample partitioned for 1000 sec. The hardness of the samples partitioned at $390{ }^{\circ} \mathrm{C}$ for $10-1000 \mathrm{sec}$ increased from $296 \mathrm{HV}$ $(\mathrm{Pt}=10 \mathrm{sec})$ to $441 \mathrm{HV}(\mathrm{Pt}=1000 \mathrm{sec})$; this could be related to increase in carbon content in $\gamma_{R}$ by increasing the Pt. Considering the UTS, YS, total elongation, toughness and HV, within the samples investigated in the present study, it is concluded that, a PT of $390{ }^{\circ} \mathrm{C}$ and a $\mathrm{Pt}$ of $500 \mathrm{sec}$ could be the best partitioning temperature and time for the Q-P process in the present steel.

\section{References}

[1] R.D.K. Misra, H. Nathani, J.E. Hartmann, F. Siciliano, Microstructural evolution in a new 770 MPa hot rolled $\mathrm{Nb}-\mathrm{Ti}$ microalloyed steel, Materials Science and Engineering A $394 \quad$ (2005) 339-352. https://doi.org/10.1016/j.msea.2004.11.041

[2] P. Liu, X. Yu, K. Wang, B. Zhu, J. Li, Y. Zhang, A new hot stamping process with quenching and partitioning treatment, $\quad$ Advanced $\quad$ Materials $\quad$ Research $\quad 1095 \quad$ (2015) https://doi.org/10.4028/www.scientific.net/AMR.1095.673

[3] J. Dong, C. Li, C. Liu, Y. Huang, L. Yu, H. Li, Y. Liu, Microstructural and mechanical properties development during quenching-partitioning-tempering process of $\mathrm{Nb}$-V-Ti micro alloyed ultra-high strength steel, Materials Science \& Engineering A 705 (2017) 249-256. https://doi.org/10.1016/j.msea.2017.08.081

[4] K. Zhang, P. Liu, W. Li, F. Ma, Z. Guo, Y. Rong, Enhancement of the strength and ductility of martensitic steels by carbon. Mater. Sci. Eng. A 716 (2018) 87-91. https://doi.org/10.1016/j.msea.2018.01.012

[5] A.J. Clarke, J.G. Speer, M.K. Miller, R.E. Hackenberg, D.V. Edmonds, D.K. Matlock, F.C. Rizzo, K.D. Clarke, E.De Moor, Carbon partitioning to austenite from martensite or bainite during the quench and partition (Q\&P) process: acritical assessment, Acta Mater. 56 (2008) 16-22. https://doi.org/10.1016/j.actamat.2007.08.051

[6] J. Park, M. C. Jo, T. Song, H. S. Kim, S. S. Sohn, S. Lee, Ultra-high strength and excellent ductility inmulti-layer steel sheet of austenitic hadfield and martensitic hot-press-forming steels. Mater. Sci. Eng. A 759 (2019) $320-328$. https://doi.org/10.1016/j.msea.2019.05.046

[7] R. Blonde, E. J. Melero, L. Zhao, J. P. Wright, E. Brück, S. Van Der Zwaag, N. H. Van Dijk, High-energy X-ray diffraction study on the temperature-dependent mechanical stability of retained austenite in low-alloyed TRIP steels, Acta Materialia 60 (2012) 565-577. https://doi.org/10.1016/j.actamat.2011.10.019 
[8] G. Bansal, M. Pradeep, C. Ghosh, V. Rajinikanth, V. C. Srivastava, V.A. Bhagat, S. Kundu, Evolution of Microstructure in a Low-Si Micro-alloyed Steel Processed Through One-Step Quenching and Partitioning. Metall. Mater. Trans. A 50 (2019) 547-555. https://doi.org/10.1007/s11661-018-5039-8

[9] J. Hang, H. Ding, R. Misra, C. Wang, Microstructural evolution and consequent strengthening through niobiummicroalloying in a low carbon quenched and partitioned steel. Mater. Sci. Eng. A 641 (2015) 242-248. https://doi.org/10.1016/j.msea.2015.06.050

[10] E. P. Uorinen, A. G. Özügürler, J. C. Ion, K. Eriksson, M. C. Somani, L. P. Karjalainen, S. Allain, F. G. Caballero, Hot forming of ultra-fine-grained multiphase steel products using press hardening combined with quenchingand partitioning process. Metals 9 (2019) 357. https://doi.org/10.3390/met9030357

[11] P. Huyghe, L. Malet, M. Caruso, C. Georges, S. Godet, On the relationship between the multiphase microstructure and the mechanical properties of a $0.2 \mathrm{C}$ quenched and partitioned steel.Mater. Sci. Eng. A 701 (2017) 254-263. https://doi.org/10.1016/j.msea.2017.06.058

[12] D. De Knijf, C. Föjer, L. A. I. Kestens, and R. Petrov, Factors influencing the austenite stability during tensile testing of Quenching and Partitioning steel determined via in-situ Electron Backscatter Diffraction, Materials Science and Engineering: A 638 (2015) 219-227. https://doi.org/10.1016/j.msea.2015.04.075

[13] D. De Knijf, E. P. Da Silva, C. Föjer, and R. Petrov, Study of heat treatment parameters and kinetics of quenching and partitioning cycles, Materials Science and Technology, 31 (2015) 817-828. https://doi.org/10.1179/1743284714Y.0000000710

[14] D. De Knijf, R. Petrov, C. Föjer, and L. A. I. Kestens, Effect of fresh martensite on the stability of retained austenite in quenching and partitioning steel, Materials Science and Engineering A, 615 (2014) 107-115. https://doi.org/10.1016/j.msea.2014.07.054

[15] G. Khalaj, H. Pouraliakbar, K. R. Mamaghani, M. J. Khalaj, Modeling the correlation between heat treatment, chemical composition and bainite fraction of pipeline steels by means of artifcial neural networks, 1(2013) 351-368.

[16] J. Zhang, H. Ding, R. Misra, C. Wang, Microstructural evolution and consequent strengthening through niobium-microalloying in a low carbon quenched and partitioned steel, Mater. Sci. Eng. A 641 (2015) 242-248. https://doi.org/10.1016/j.msea.2015.06.050

[17] L.L. Wu, T.K. Yao, J.W. Zhang, F.R. Xiao, Understanding the mechanical properties of vanadium carbides: Nano-indentation measurement and first-principles calculations, J. Alloy. Compd. 548 (2013) 60-64. https://doi.org/10.1016/j.jallcom.2012.09.014

[18] Z. Xiaosheng, L. Chenxi, Y. Liming, L. Yongchang, L. Huijun, Phase Transformation Behavior and Microstructural Control of High-Cr Martensitic/Ferritic Heat-resistant Steels for Power and Nuclear Plants: A Review, Journal of Materials Science \& Technology 31 (2015) 235-242. https://doi.org/10.1016/j.jmst.2014.12.001

[19] D.T Pierce, D.R. Coughlin, D.L Williamson, K.D Clarke, A.J Clarke, J.G Speer, E. De Moor, Characterization of transition carbides in quench and partitioned steel microstructures by Mössbauer spectroscopy and complementary techniques, Acta Mater. 90 (2015) 417-430. https://doi.org/10.1016/j.actamat.2015.01.024

[20] S. Yan, X. Liu, Microstructure and mechanical properties of a low-carbon steel treated by one-step quenching and partitioning process, in Advanced Materials Research, 1082 (2015) 202-207. https://doi.org/10.4028/www.scientific.net/AMR.1082.202 
[21] N. Zhong, Q. Wu, Y. Yin, and X. Wang, Micro-structural evolution of a medium carbon advanced high strength steel heat-treated by quenching-partitioning process, Steel Research International, 86 (2015) 252-256. https://doi.org/10.1002/srin.201400064

[22] Y. Toji, G. Miyamoto, D. Raabe, Carbon partitioning during quenching and partitioning heat treatment accompanied by carbide precipitation, Acta Materialia, $86 \quad$ (2015) 137-147. https://doi.org/10.1016/j.actamat.2014.11.049

[23] P. Liu, B. Zhu, Y. Wang, Y. Zhang, Coupled Model for Carbon Partitioning from Martensite into Austenite during the Quenching Process in Fe-C Steels, the Minerals, Metals \& Materials Society and ASM International 2016. https://doi.org/10.1007/s11661-016-3560-1

[24] F. Peng, Y. Xu, J. Li, X. Gu, X. Wang, Interaction of martensite and bainite transformations and its dependence on quenching temperature in intercritical quenching and partitioning steel, Mater. Des. 181 (2019) 107921. https://doi.org/10.1016/j.matdes.2019.107921

[25] M.J. Santofimia, J.G. Speer, A.J. Clarke, L. Zhao, J. Sietsma, Influence of interface mobility on the evolution of austenite-martensite grain assemblies during annealing, Acta Mater. 57 (15) (2009) 4548-4557.

https://doi.org/10.1016/j.actamat.2009.06.024

[26] V. F. Zackay, M. D. Bhandarkar, and E. R. Parker, The Role of Deformation-Induced Phase Transformations in the Plasticity of Some Iron-Based Alloys, in Advances in Deformation Processing, pp. 351-404, 1978.

[27] P. Huyghe, L. Malet, M. Caruso, C. Georges, S. Godet, On the relationship between the multiphase microstructure and the mechanical properties of a $0.2 \mathrm{C}$ quenched and partitioned steel, Mater. Sci. Eng. A 701 (2017) 254-263. https://doi.org/10.1016/j.msea.2017.06.058

[28] P. Kantanen, M. Somani, A. Kaijalainen, O. Haiko, D. Porter, J. Komi, Microstructural Characterization and Mechanical Properties of Direct Quenched and Partitioned High-Aluminum and High-Silicon Steels, Metals 9 (2019) 256. https://doi.org/10.3390/met9020256

[29] M. Pozuelo, J.W. Stremfel, J.M. Yang, J. Marian, Strengthening to softening transition in lath martensite. Materialia, 5 (2019) 100254. https://doi.org/10.1016/j.mtla.2019.100254

[30] M. Cheng, H. W. Song, X. Li, S. H. Zhang, and T. Lin, Effects of Quenching and Partitioning Process on Mechanical Properties of a Hot-Stamping Steel, Materials Science Forum 788 (2014) 340-345. https://doi.org/10.1007/s42243-018-0183-3

[31] S. Kim, C. G. I. L. Lee, I. Choi, S. Lee, Effects of Heat Treatment and Alloying Elements on the Microstructures and Mechanical Properties of 0.15 Wt Pct C Transformation-Induced Plasticity-Aided Cold-Rolled Steel Sheets, Metallurgical and Materials Transactions A 32 (2001) 505-514. https://doi.org/10.1007/s11661-001$\underline{0067-0}$

[32] E. C. Bain, Functions of Alloying Elements in Steel, 1st ed. Chicago: ASM International, 1939.

[33] H. Bhadeshia, R. Honeycombe, Steels: Microstructure and Properties, 3rd ed. Elsevier Inc., 2006.

[34] J. Tobata, K.L. Ngo-Huynh, N. Nakada, T. Tsuchiyama, S. Takaki, Role of silicon in quenching and partitioning treatment of low-carbon martensitic stainless steel, ISIJ Int. 52 (2012) 1377-1382. https://doi.org/10.2355/isijinternational.52.1377

[35] J. Mahieu, B. C. Cooman, and S. Claessens, Galvanizability of high-strength steels for automotive applications, Metallurgical and Materials Transactions A 32 (2001) 2905-2908. https://doi.org/10.1007/s11661-001-1042-5 
[36] M. De Meyer, D. Vanderschueren, B. C. De Cooman, and K. E. Y. Wor, The Influence of the Substitution of Si by $\mathrm{Al}$ on the Properties of Cold Rolled C-Mn-Si TRIP Steels, ISIJ International, 39 (1999) 813-822. https://doi.org/10.2355/isijinternational.39.813

[37] E.S. Rowland, S.R. Lyle, The application of MS points to case depth measurement, Trans. ASM 37 (1946) 2747.

[38] S. Hartmann, H. Ruppersberg, Thermal expansion of cementite and thermo-elastic stresses in white cast iron, Mater. Sci. Eng. A 190 (1995) 231-239. https://doi.org/10.1016/0921-5093(94)09616-5

[39] C.F. Jatczak, Retained Austenite and Its Measurement By X-Ray Diffraction, SAE International, 1980. 
Figures
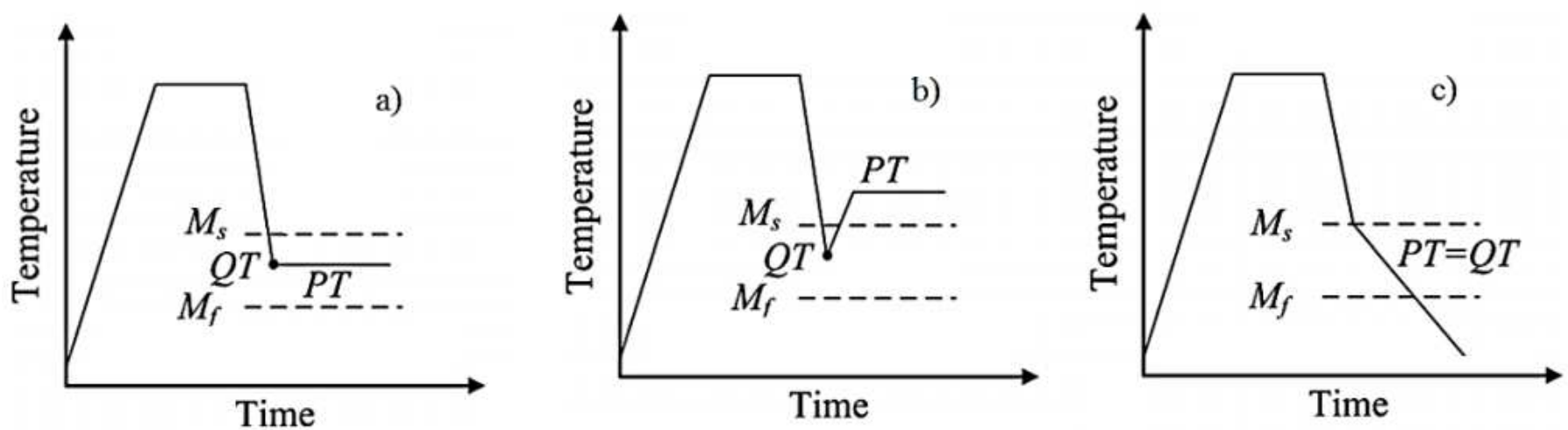

Figure 1

Please see the Manuscript PDF file for the complete figure caption

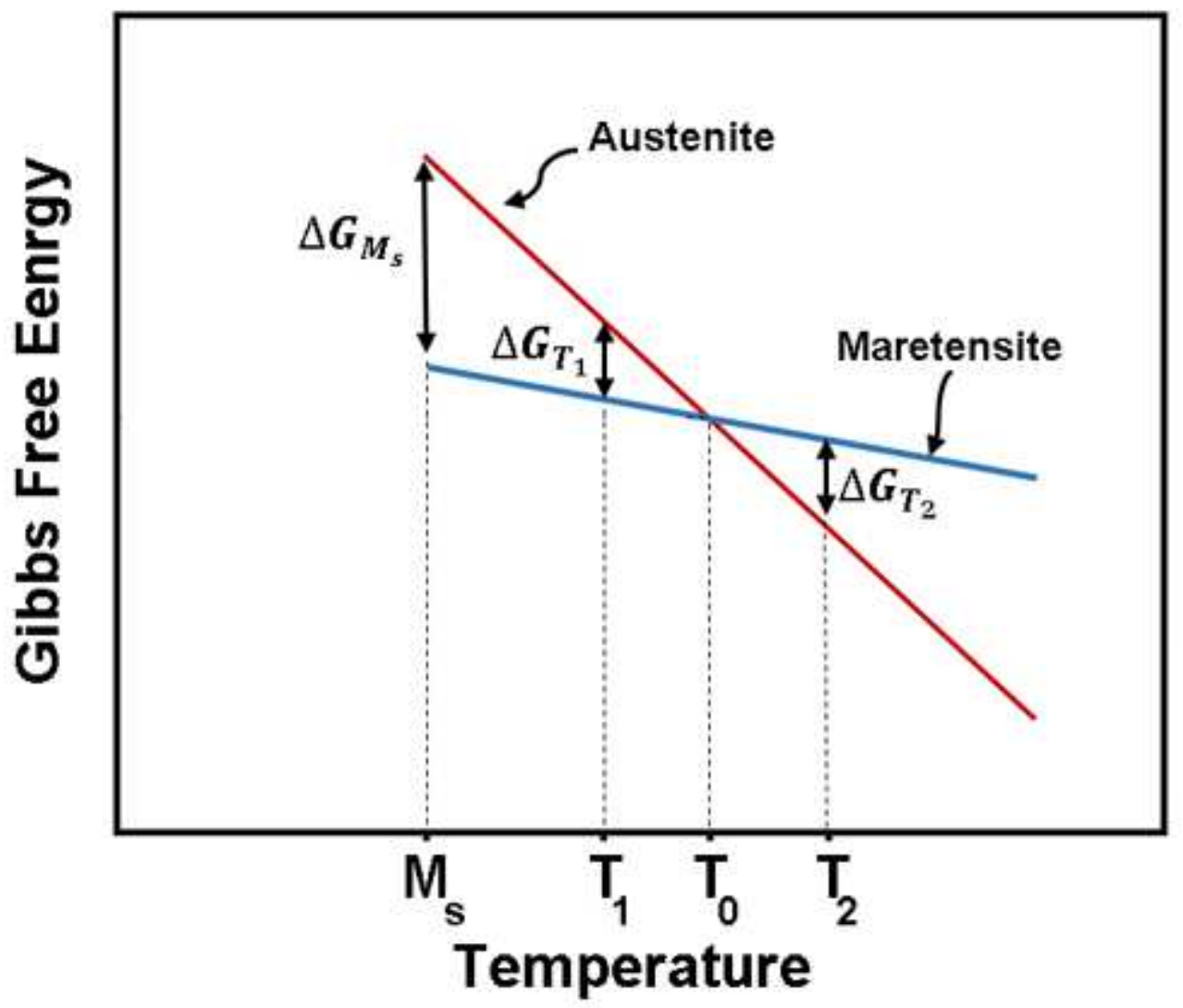

Figure 2

Please see the Manuscript PDF file for the complete figure caption 
a)

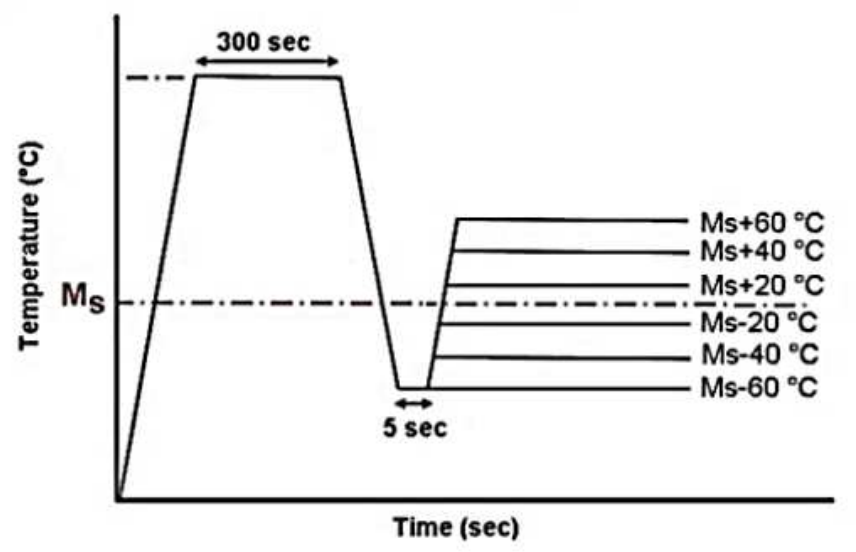

b)

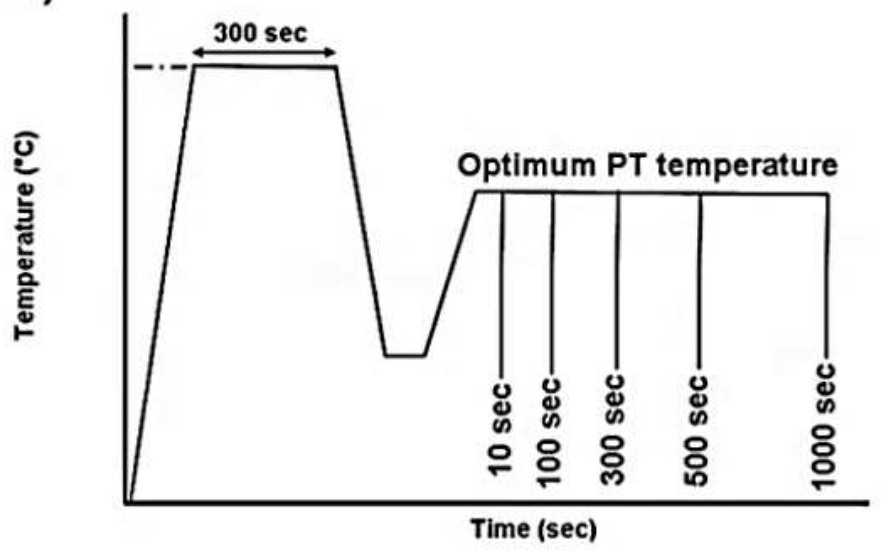

Figure 3

Please see the Manuscript PDF file for the complete figure caption

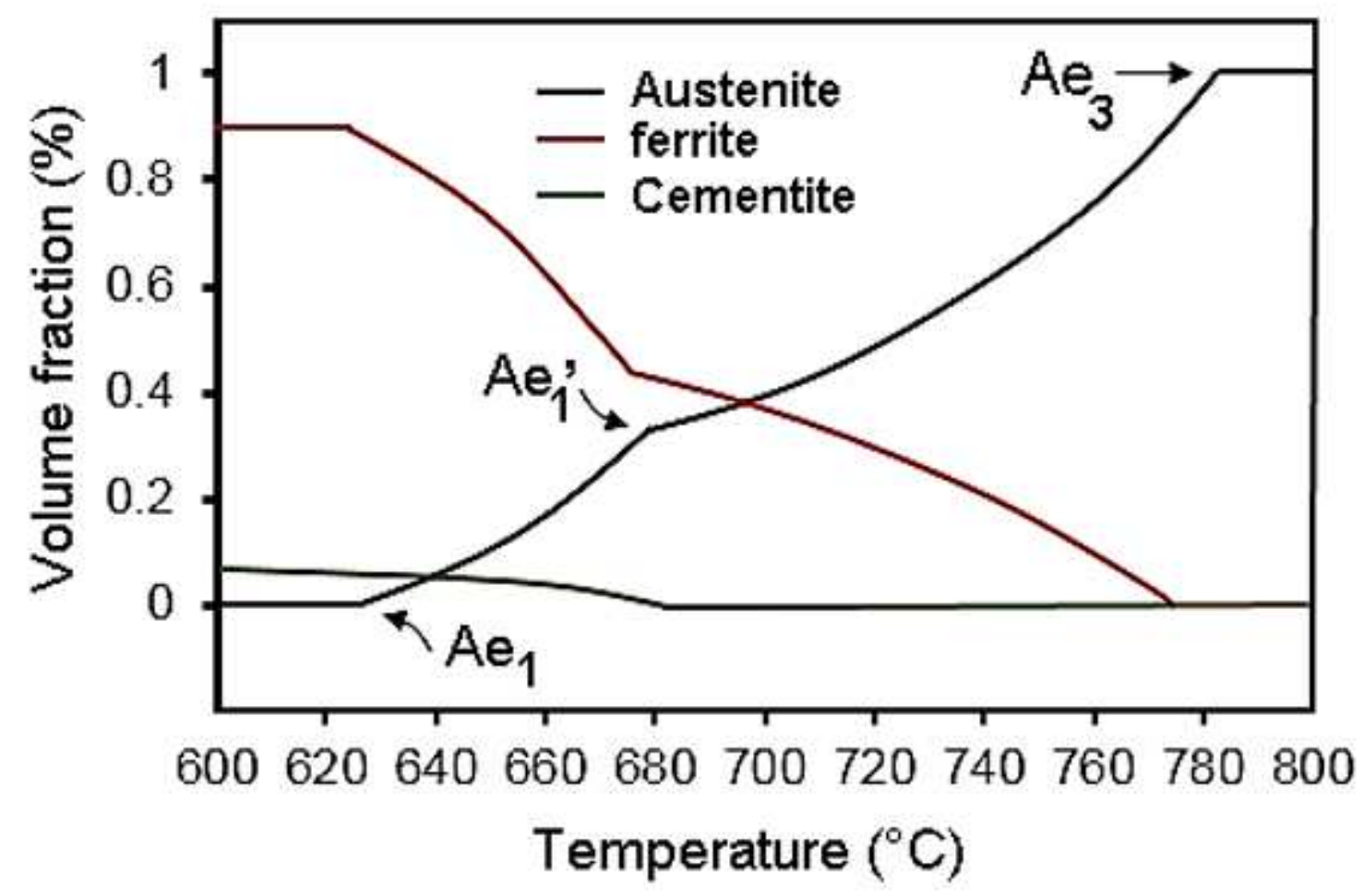

Figure 4

Please see the Manuscript PDF file for the complete figure caption 


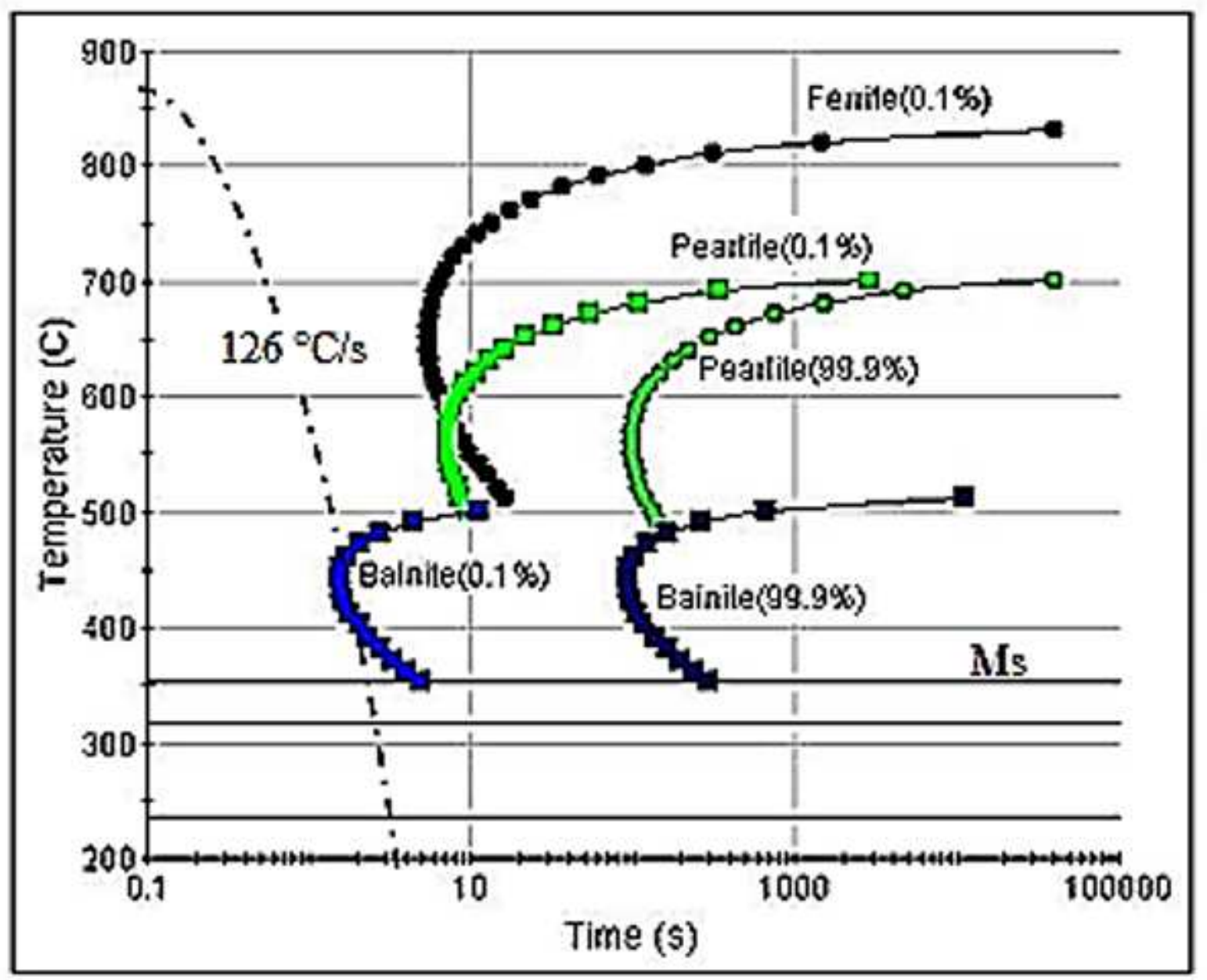

Figure 5

Please see the Manuscript PDF file for the complete figure caption 

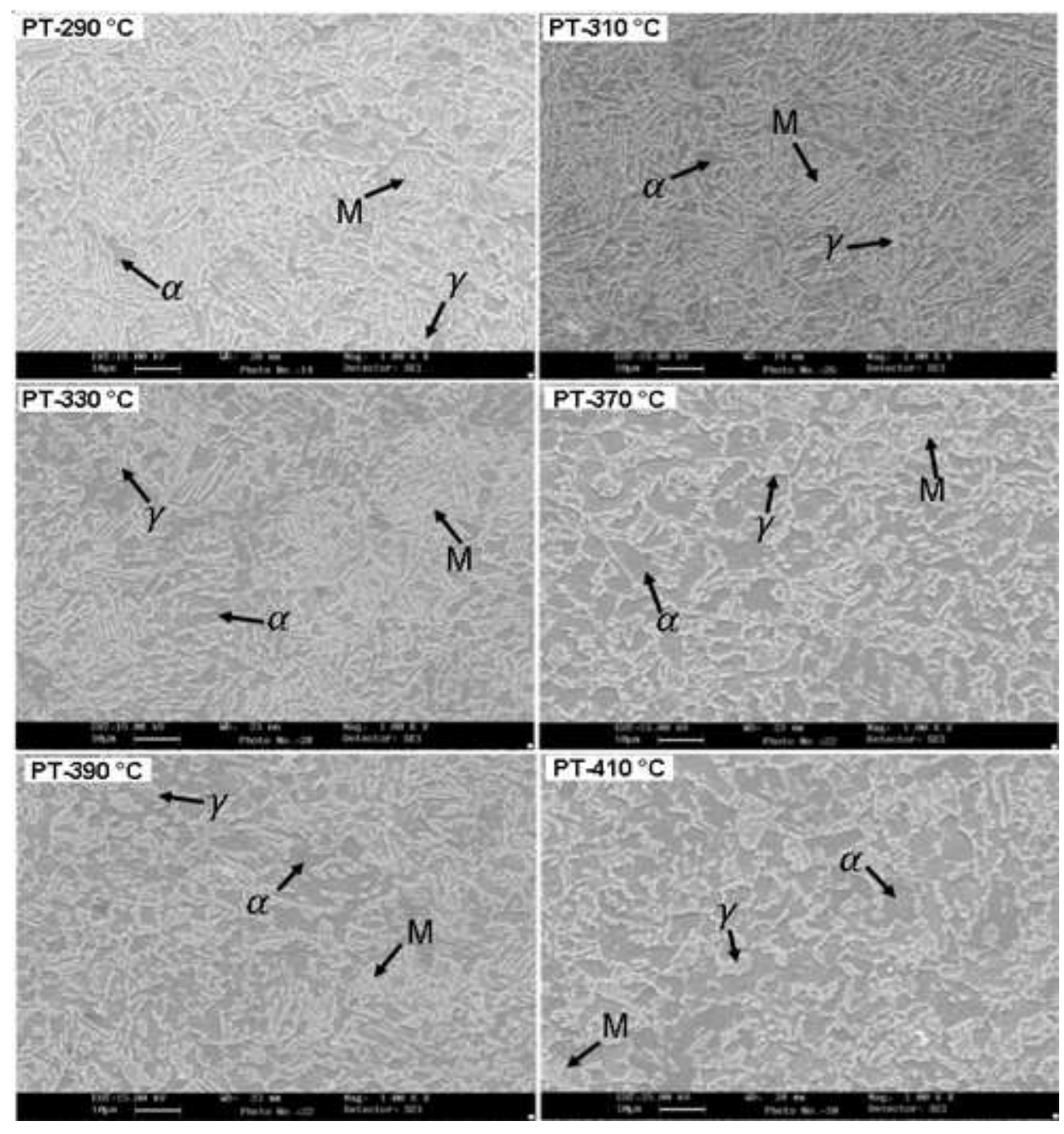

Figure 6

Please see the Manuscript PDF file for the complete figure caption 


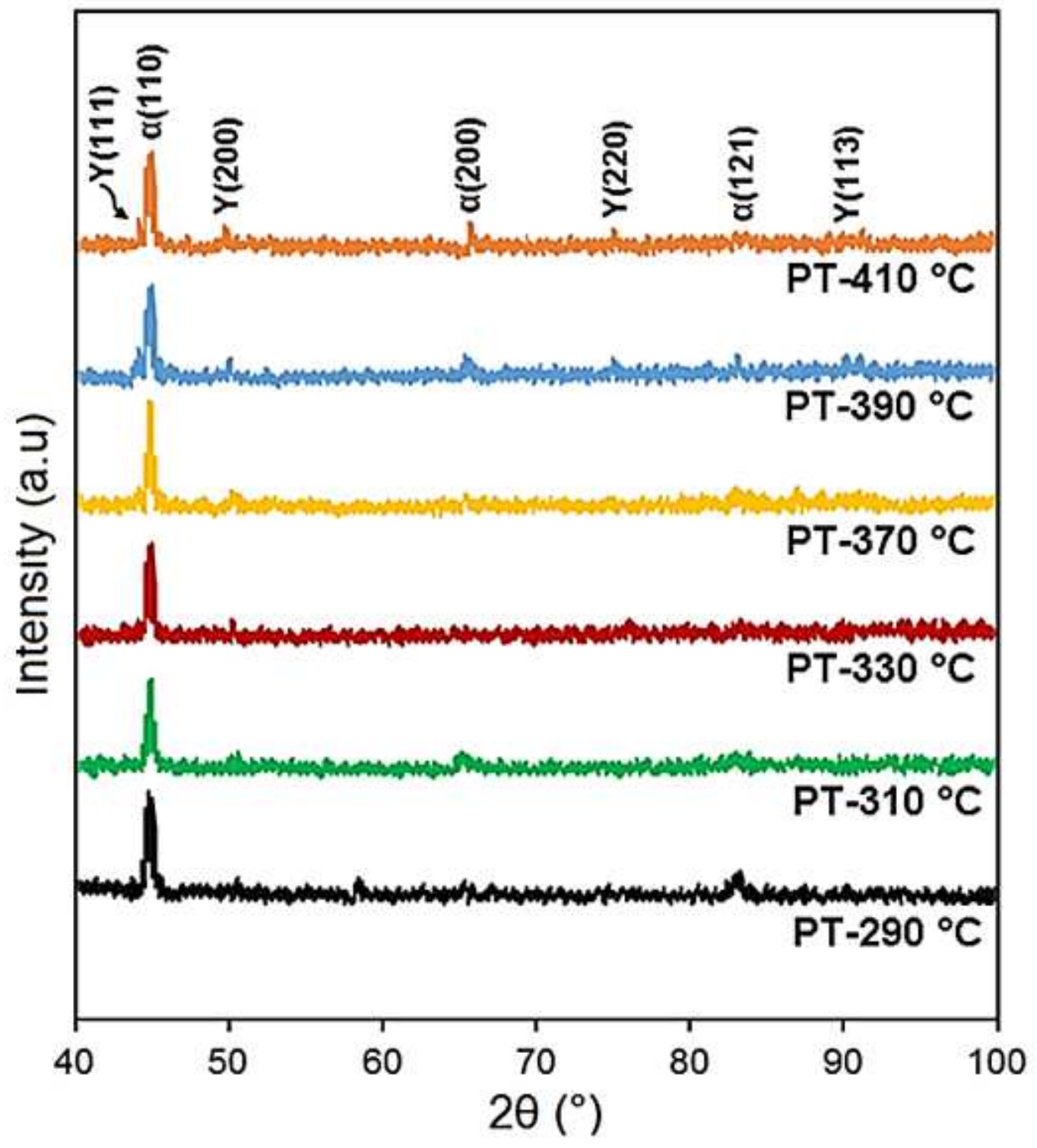

Figure 7

Please see the Manuscript PDF file for the complete figure caption 


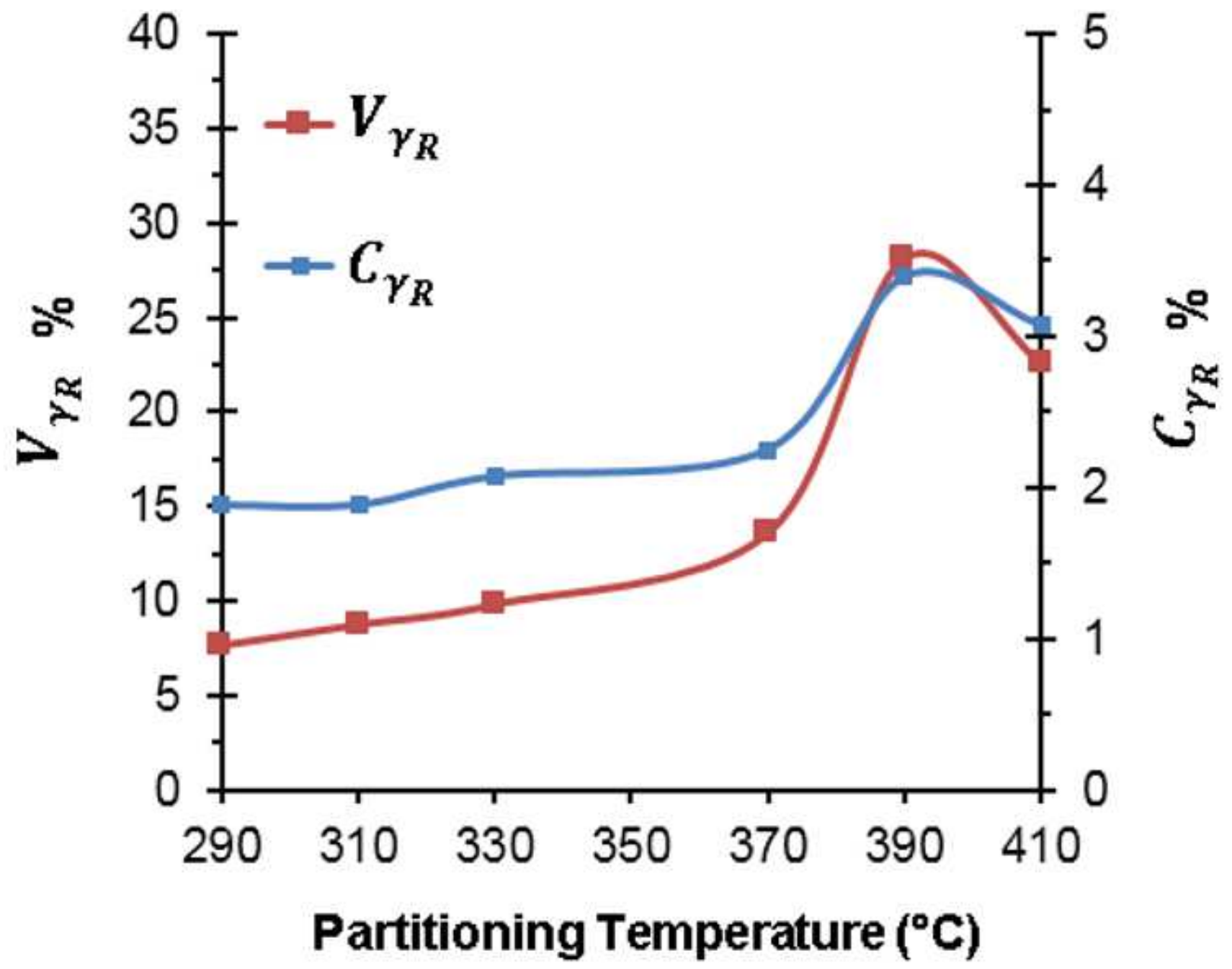

Figure 8

Please see the Manuscript PDF file for the complete figure caption 


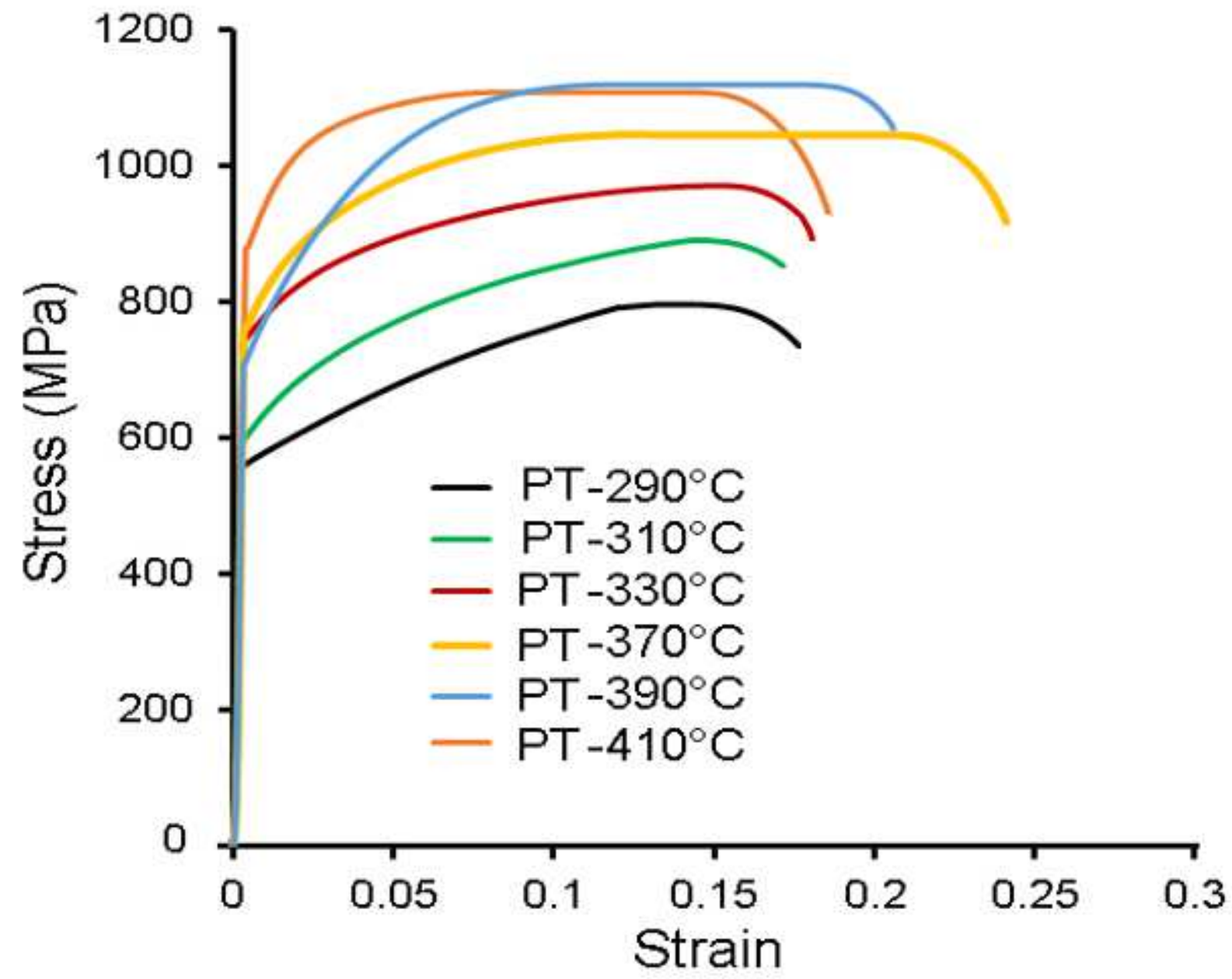

Figure 9

Please see the Manuscript PDF file for the complete figure caption 


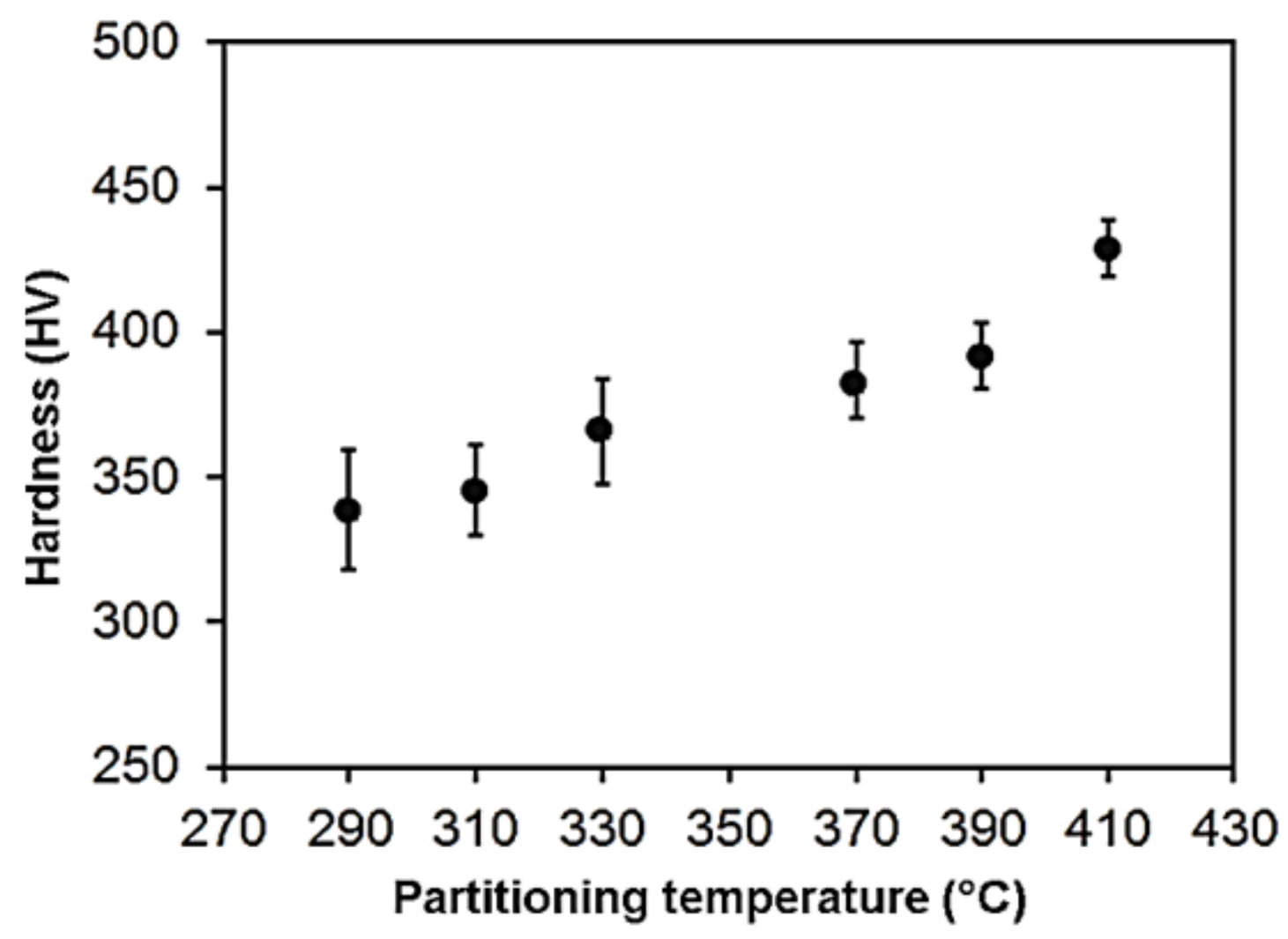

Figure 10

Please see the Manuscript PDF file for the complete figure caption 


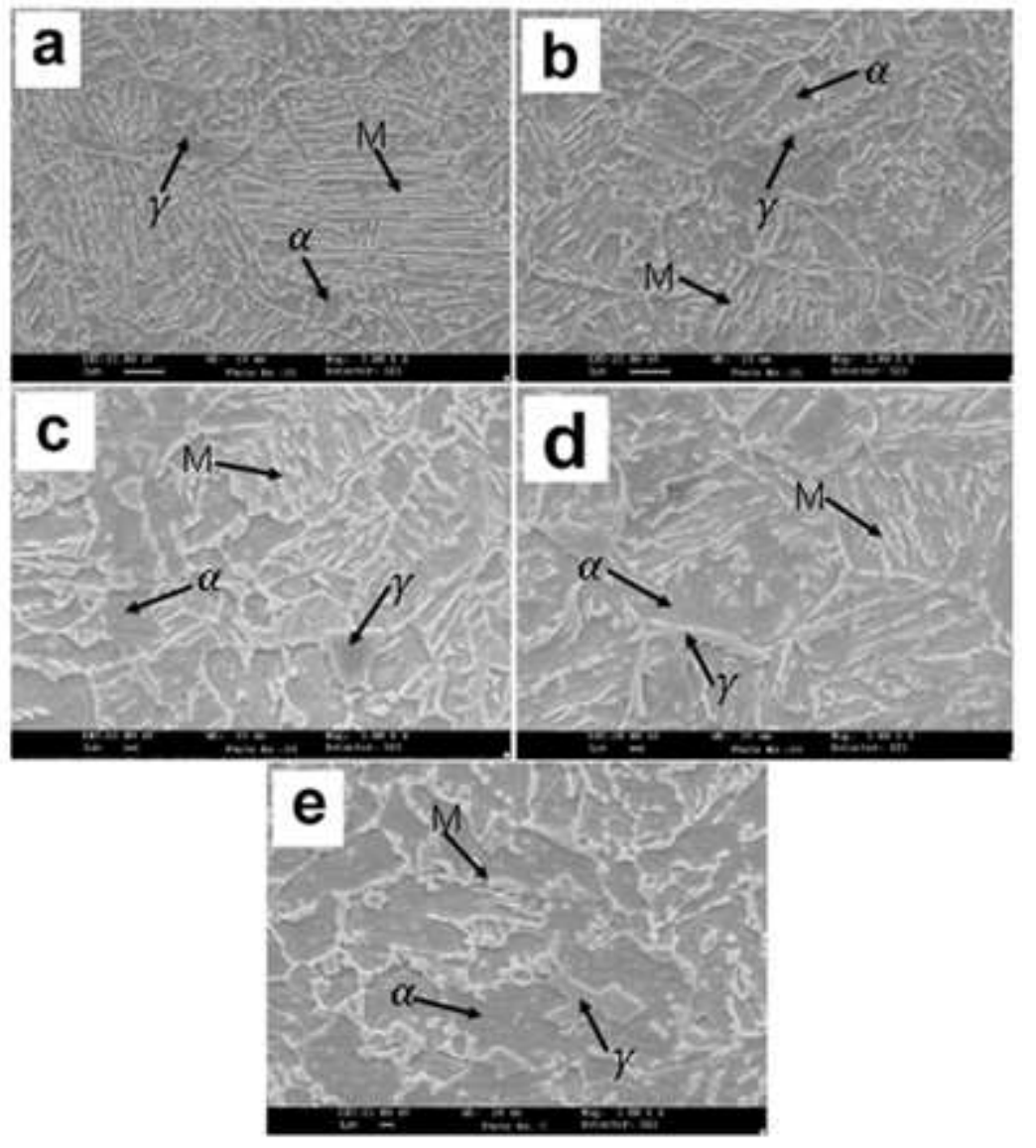

Figure 11

Please see the Manuscript PDF file for the complete figure caption 


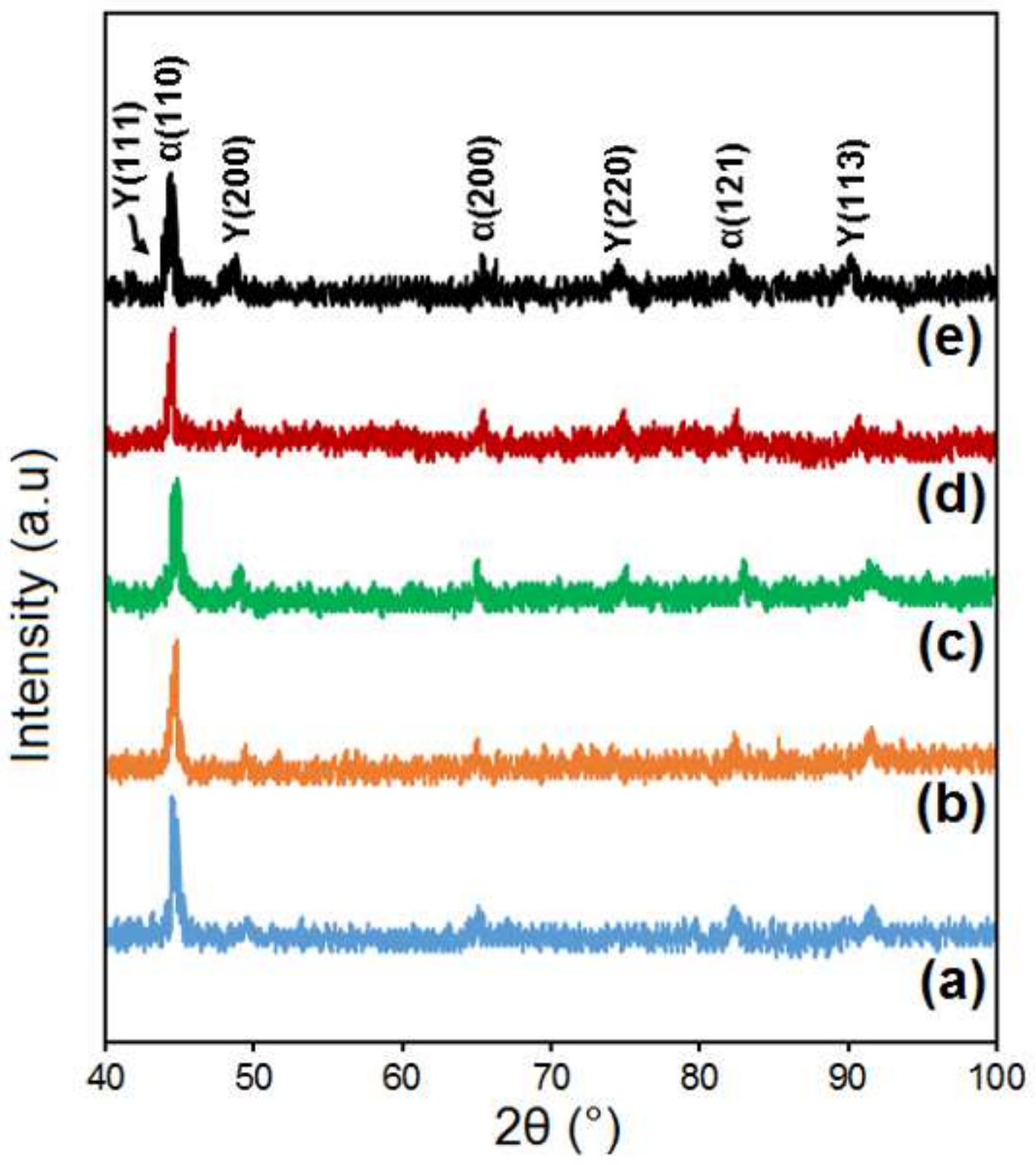

Figure 12

Please see the Manuscript PDF file for the complete figure caption 


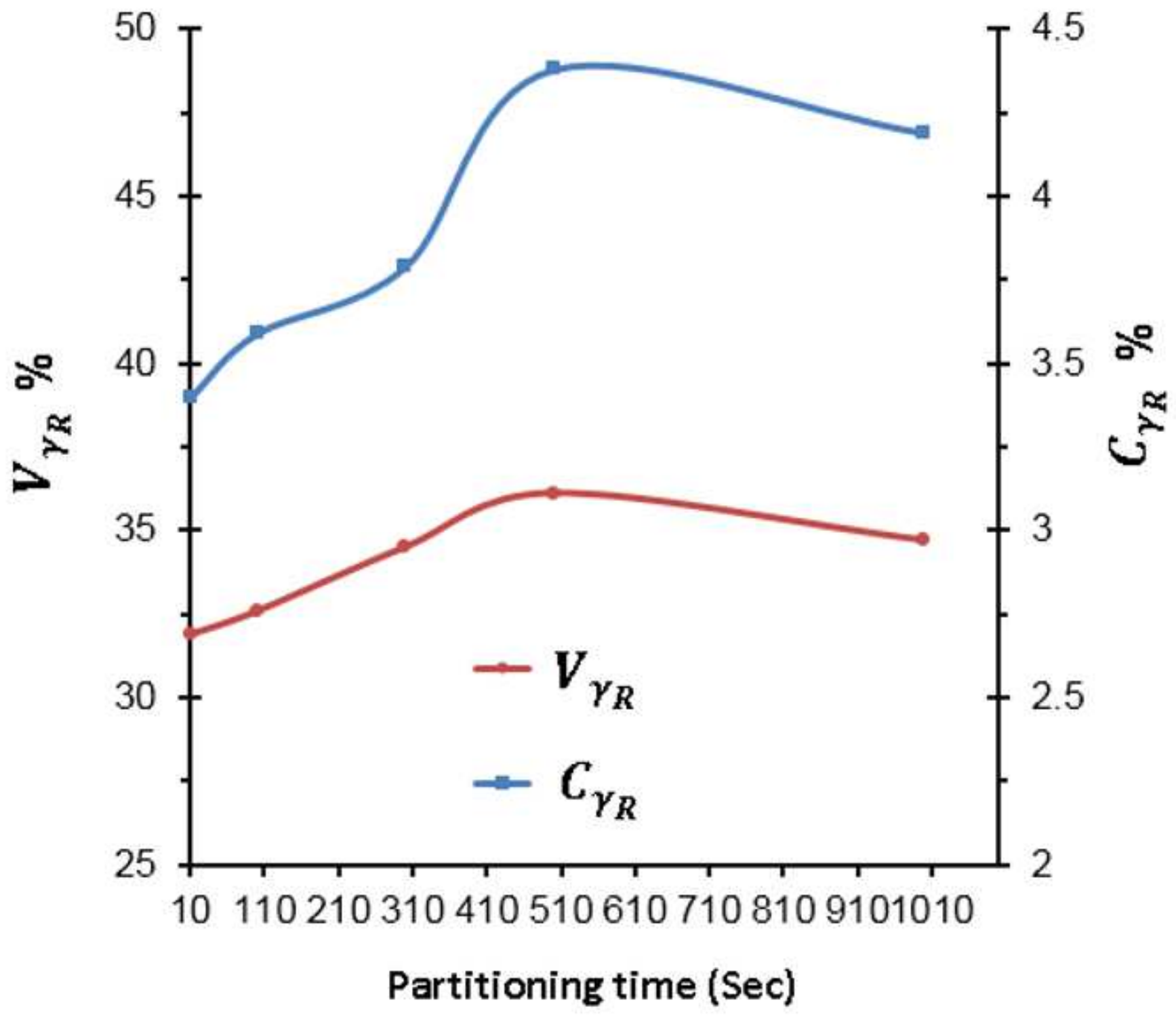

Figure 13

Please see the Manuscript PDF file for the complete figure caption 


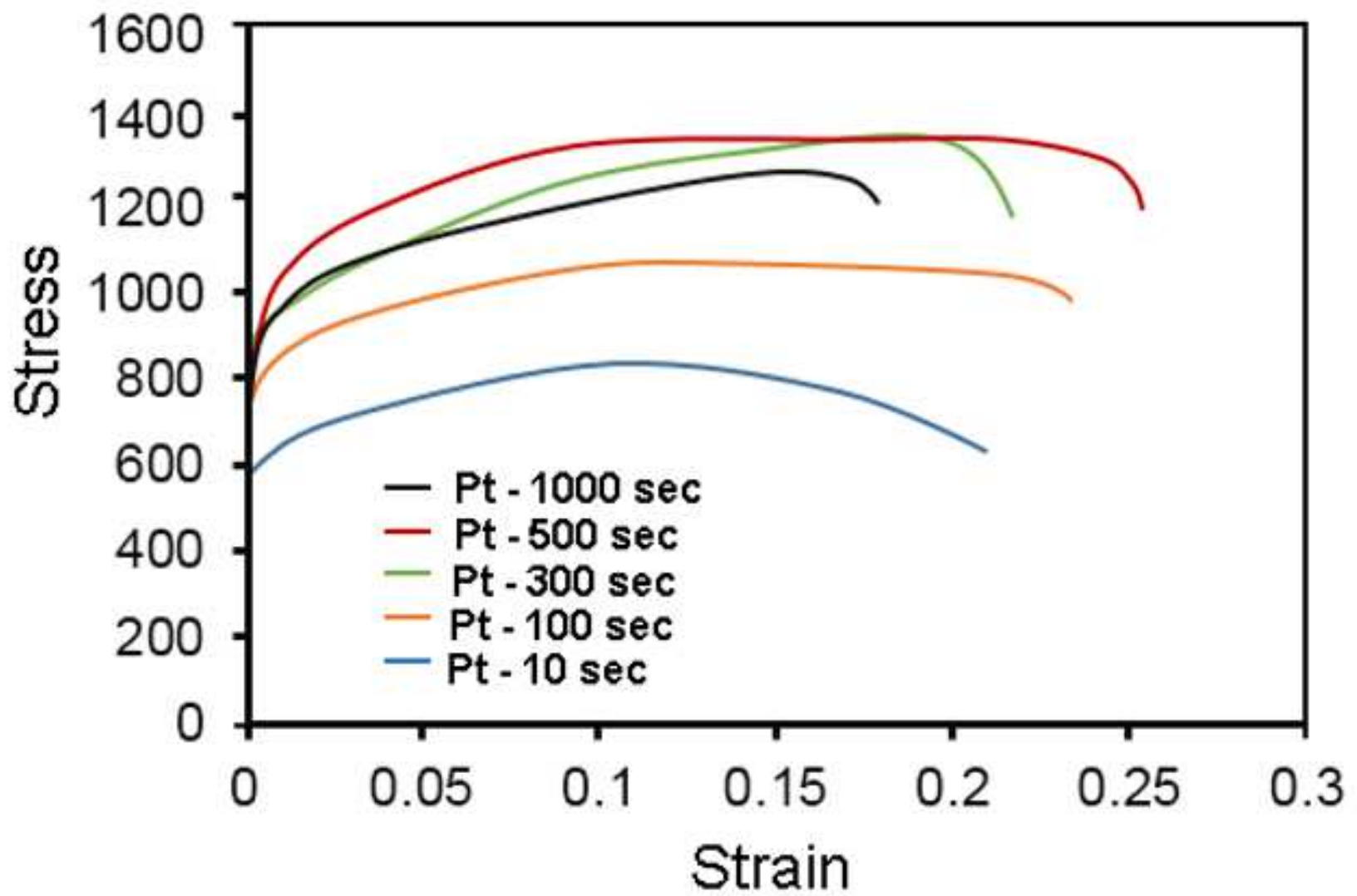

Figure 14

Please see the Manuscript PDF file for the complete figure caption

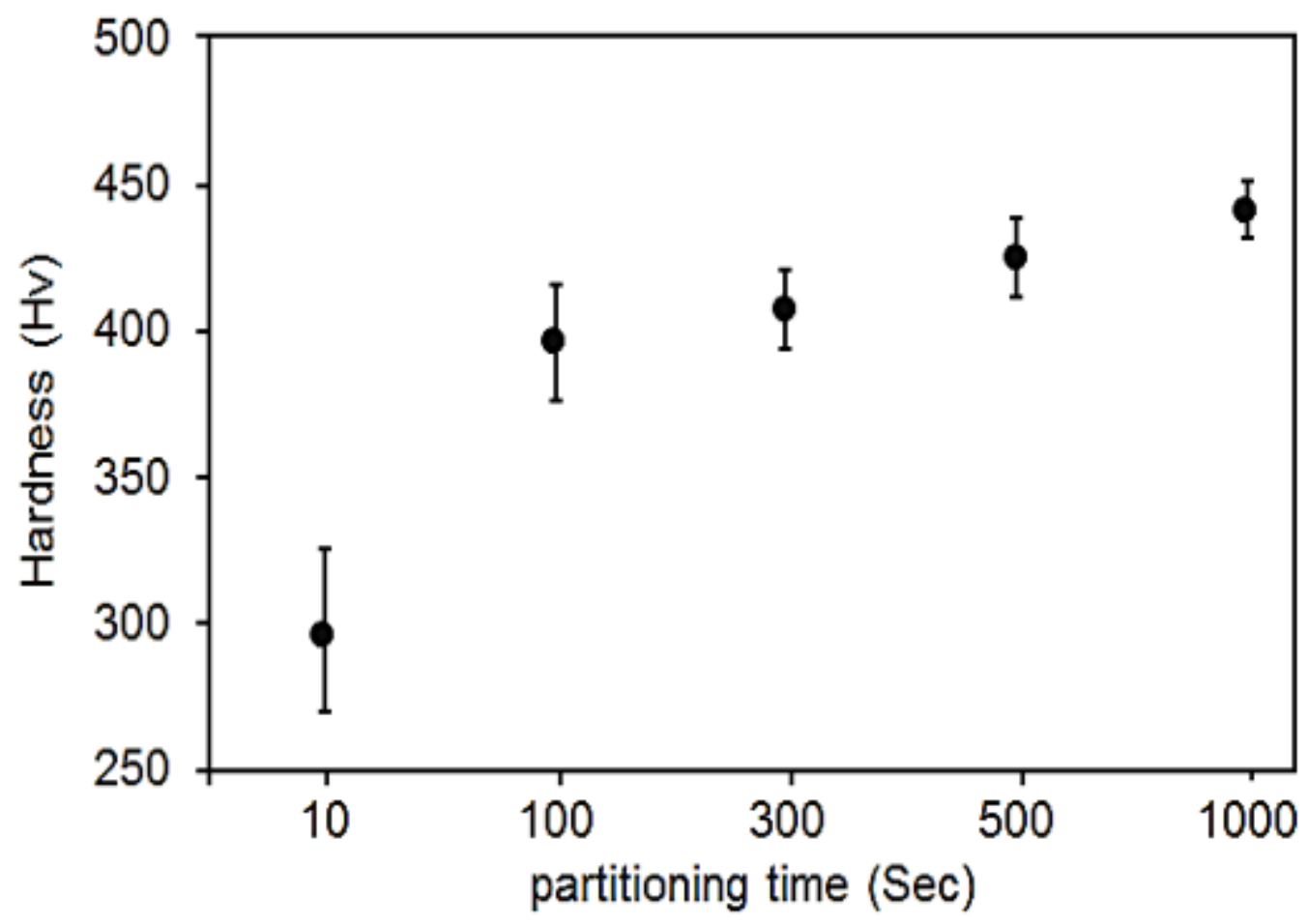


Figure 15

Please see the Manuscript PDF file for the complete figure caption 